\title{
Tectonostratigraphic and petrogenetic setting of late Mississippian volcanism in eastern Canada
}

\begin{tabular}{|r|l|}
\hline Journal: & Canadian Journal of Earth Sciences \\
\hline Manuscript ID & cjes-2017-0176.R1 \\
\hline Manuscript Type: & Article \\
\hline Date Submitted by the Author: & 27-Nov-2017 \\
\hline $\begin{array}{r}\text { Complete List of Authors: } \\
\text { Is the invited manuscript for } \\
\text { consideration in a Special } \\
\text { Issue? : }\end{array}$ & $\begin{array}{l}\text { Jutras, Pierre; Dept of Geology } \\
\text { Kostal, Jaroslav; Saint Mary's University, Geology } \\
\text { Matheson, Zachary; Saint Mary's University, Geology }\end{array}$ \\
\hline Keyword: & $\begin{array}{l}\text { alkali basalt, clastic sedimentology, felsic volcanic rocks, pull-apart basin, } \\
\text { trace element geochemistry }\end{array}$ \\
\hline &
\end{tabular}




\section{Tectonostratigraphic and petrogenetic setting of late Mississippian}

\section{volcanism in eastern Canada}

Pierre Jutras, Jaroslav Dostal, Sandra Kamo, and Zachary Matheson

P. Jutras, J. Dostal and Z. Matheson. Department of Geology, Saint Mary’s University, Halifax, Nova Scotia, B3H 3C3, Canada.

S. Kamo. Department of Earth Sciences, University of Toronto, 22 Russell St., Toronto, Ontario, M5S 3B1, Canada.

Corresponding author: Pierre Jutras (e-mail: pierre.jutras@smu.ca) 
Abstract: In the aftermath of the Middle Devonian Acadian Orogeny, a thick mafic body is inferred to have been emplaced at the base of the crust during development of the Maritimes Basin complex in eastern Canada, and is believed to have sourced regional Late Devonian to Mississippian volcanism. By late Mississippian times, volcanism was limited to central New Brunswick and the Magdalen Islands of eastern Quebec. Whereas Late Devonian to early Mississippian mafic volcanism was mainly characterized by sub-alkaline lavas produced by the high-degree partial melting of a subduction-enriched lithospheric mantle source, late Mississippian volcanism was dominated by alkali mafic lavas produced by the low-degree partial melting of a sub-lithospheric mantle source that shows no evidence of subduction imprint. Two distinct upper Mississippian volcanic successions were identified in central New Brunswick and are estimated to be separated by $\sim 7 \mathrm{My}$ based on U-Pb ID-TIMS dates on felsic intervals. They respectively belong to the Cumberland Hill Formation and a new volcanic member of the Hopewell Cape Formation. As they share close geochemical affinities, we interpret both volcanic units as having been derived from the same primary source, but from distinct magmatic pulses. Based on the sedimentology of interbedded clastic units as well as available mapping and geophysical data in New Brunswick, we interpret that the upper Mississippian mafic lavas were issued from large NW-SE striking dykes responding to NW-SE compression in a pull-apart basin, whereas less voluminous and more localised felsic rocks where possibly issued from discrete volcanic pipes.

Keywords: alkali basalt, clastic sedimentology, felsic volcanic rocks, pull-apart basin, trace element geochemistry 


\section{Introduction}

Following the Middle Devonian Acadian Orogeny, eastern Canada evolved as a complex system of strike-slip basins that hosted widespread and locally abundant Upper Devonian to Tournaisian (lower Mississippian) volcanic rocks (Gibling et al., 2008; Hibbard and Waldron, 2009). Upper Mississippian volcanic rocks are more restricted and only known from central New Brunswick (Fyffe and Barr, 1986; Gray et al., 2010) and the Magdalen Islands of eastern Quebec (Barr et al., 1985; La Flèche et al., 1998; Giles, 2008) (Fig. 1). Whereas the Magdalen Island occurrences (Cap Adèle Member of the Hâvre aux Maisons Formation) are interbedded with fossiliferous marine sedimentary rocks dated as upper Asbian (Giles, 2008), the New Brunswick occurrences are interbedded with undated red beds in a continental basin that was fragmented by early Pennsylvanian deformation and that is mostly buried below Pennsylvanian strata (Jutras et al., 2007a), all of which has historically led to uncertainties in stratigraphic correlations.

However, the study of interbedded coarse clastic rocks can provide valuable information on the tectonic setting of such intrabasinal volcanic rocks.

In this paper, we reconstruct the tectonic, stratigraphic, paleogeographic and petrogenetic settings of upper Mississippian volcanic units from central New Brunswick by studying and comparing their geochemistry and stratigraphic relationships, by using constraints provided by the sedimentology of interbedded sedimentary units, and by differentiating pre-, syn- and postemplacement structures with mapping, well and geophysical data. To better constrain the age and stratigraphic relationships, we dated a thin interval of felsic tuff at the base of the volcanic succession at one locality (Hardwood Ridge), as well as a rhyolite boulder in the conglomerate that lies conformably below that succession. These data were then compared with available data 
from penecontemporaneous mafic rocks of the Magdalen Islands (La Flèche et al., 1998; Giles, 2008) to produce a general model for late Mississippian volcanism in eastern Canada.

\section{Geological setting}

The Late Devonian to Mississippian volcanic rocks of eastern Canada and the sub-basins that host them are part of the composite Late Devonian to Early Permian Maritimes Basin (Gibling et al. 2008). Sedimentary rocks from the Late Devonian to Mississippian interval were deposited in large transtensional sub-basins and small compressional and extensional sub-basins in response to NW-SE shortening (Jutras and Prichonnet, 2005; Jutras et al., 2005, 2007a, 2016). In late Mississippian times, subbasins in the east and southeast sectors of the Maritimes Basin were accommodating the restricted epicontinental sea deposits of the Windsor Group, whereas those to the northwest were accommodating continental clastic rocks of the Percé Group (Gibling et al., 2008), with southern New Brunswick showing the lateral transition between the two groups (Jutras et al., 2016). Upper Mississippian volcanic rocks are found within the continental Percé Group in the Central-Marysville Basin of New Brunswick, but within the dominantly marine Middle Windsor Group in the Magdalen Basin of eastern Quebec (Giles, 2008). They are concentrated to the north of the Belleisle Fault and its approximate extension into the Gulf of Saint-Lawrence (Fig. 1, inset). In New Brunswick, this fault separates the Avalon Zone to the south from the Gander Zone to the north (sensu Williams, 1995). 


\section{Stratigraphy of upper Mississippian units in central New Brunswick}

Twenty field and well sections showing upper Mississippian rocks in central New Brunswick were included in this study to provide tectonostratigraphic constraints, paleocurrent vectors, and lateral facies variation data for our reconstruction of the paleogeographic and tectonic settings in which volcanism of that age occurred in that area (Fig. 1). Emphasis was placed on four key sections and one deep borehole that provide a stratigraphic context to the upper Mississippian volcanic units in central New Brunswick (Fig. 3, localities 6, 9-11 and 16).

\section{Lower Windsor Group and La Coulée Calcrete}

The base of the upper Mississippian succession in central New Brunswick is characterized by marine deposits of the Holkerian (sensu Menning et al., 2006) Lower Windsor Group (Fig. 2), which is only exposed in the southern part of the Central-Marysville Basin (Jutras et al., 2007b). Paraconformably above Upper Devonian volcanic and sedimentary rocks of the Piskahegan Group, basal Windsor Group beds are characterized by delta deposits of the Meaghers Grant Formation at localities 10 and 15, or by carbonate banks of the Gays River Formation at localities 15-16 (Fig. 1). At localities 17-18 (Fig. 1), the Gays River banks are unconformably overlying Ordovician rocks and were thoroughly calcretized by fresh groundwater during a penetrative, host-replacing phreatic calcretization event that occurred at basin margins while thick Lower Windsor Group evaporites (Fig. 2) were being deposited in basin centres (Jutras et al., 2007b). Where the host material is not recognized as belonging to the Lower Windsor Group, this host-replacing phreatic calcrete is referred to as the La Coulée Calcrete (sensu Jutras and Prichonnet, 2005) (Fig. 1, localities 1, 4, and 19). 


\section{Felsic volcanic rocks of the Cumberland Hill Formation}

In central New Brunswick, a small inlier of trachyte and rhyolite that are unusually rich in incompatible trace elements (Gray et al., 2010) encompasses the only known exposures of the Cumberland Hill Formation (St. Peter, 1997) (Fig. 1, Locality 12), which is also absent from regional wells away from that area. The rhyolite was dated at $335 \pm 2 \mathrm{Ma}(\mathrm{U}-\mathrm{Pb}$ age from zircon, NBDNRE, 2010), which is upper Arundian according to Menning et al. (2000), lower Asbian according to Menning et al. (2006), and mid-Asbian according to Richards et al. (2013). The base of this felsic succession is not exposed.

\section{Tennycape Formation}

An erosion event separates Lower and Middle Windsor Group rocks (Giles et al., 1979) and also separates the lower and middle intervals of the time-equivalent Percé Group (Jutras and Prichonnet, 2005). This erosion was occurring in broad, intrabasinal, anticlinal flexures, and was sourcing the upper Holkerian to Lower Asbian Tennycape Formation (sensu Jutras et al., 2016) (Fig. 2) in synclinal subbbasins (Jutras and Prichonnet, 2005; Jutras et al., 2007a, b).

\section{Middle Windsor Group}

In central New Brunswick, Middle Windsor Group rocks (the informal Albright Brook beds) are confined to a narrow valley-fill that cuts through calcretized Lower Windsor Group carbonates (Fig. 1, locality 17) and that is interpreted to be the root of a small delta, being composed of limestone interbedded with grey siliciclastic intervals (Jutras et al., 2007b). 


\section{Shin Member of the Hopewell Cape Formation}

Conformably overlying the Middle Windsor Group Albright Brook beds at locality 17 is a coarse Visean red bed interval that was the subject of a regional correlation effort across eastern Quebec and New Brunswick, and that was eventually assigned to the Shin Member of the Hopewell Cape Formation (Percé Group) by Jutras et al. (2016) (Fig. 2). This member is similar in facies at all localities of the Central-Marysville Basin and of the nearby Ristigouche and Cumberland basins of northern and southern New Brunswick (Zaitlin and Rust, 1983; Jutras et al., 1999, 2001, 2005, 2007a-b, 2016; Jutras and Prichonnet, 2002, 2005), being dominantly comprised of red, polymictic pebble conglomerate cross-channelized with red sandstone. In central New Brunswick, they were historically assigned to the now abandoned McKinley (Freeze, 1936), Newcastle Creek (Muller, 1951) and Shin (van de Poll, 1967) formations (Fig. 2; CJES-2017-0176suppla).

Based on the above-mentioned studies, the Hopewell Cape Formation Shin Member (including the abandoned Bonaventure and Cannes-de-Roches formations) was sourced from steep fault scarps and deposited in proximal, gravelly alluvial fans and braidplains. Based on stratigraphic relationships (Figs. 1 and 2), deposition of the fault-controlled Hopewell Cape Formation began during the late Asbian (upper Visean), as this conglomeratic facies is interbedded with carbonates of that age in the nearby Cumberland Basin (Jutras et al., 2016) (Fig. 2). 


\section{Hardwood Ridge Volcanic Member of the Hopewell Cape Formation}

In central New Brunswick, red conglomerate of the Shin Member is conformably overlain by volcanic rocks that are interbedded with a similar conglomeratic facies (Fig. 3). Fyffe and Barr (1986) determined that there were significant geochemical differences between basalts that occur at the base of the post-Acadian succession in the Plaster Rock and Carlisle sub-basins of western New Brunswick (localities a and b in the inset of Fig. 1), which are assigned to the Upper Devonian to Tournaisian Gladwyn Basalt (St. Peter, 1979), and those that occur within the Carboniferous successions further east in central New Brunswick (study area indicated on Figure 1), which were historically assigned to the Boiestown (Fyffe and Barr, 1986), Royal Road (Bailey, 1910), Hardwood Ridge (Muller, 1951) and Queenstown (MacKenzie, 1964) basalts. Although bearing different stratigraphic names, these four basaltic occurrences are petrographically similar (Fyffe and Barr, 1986) and occur at the same stratigraphic interval. This volcanic succession is here assigned to the Hardwood Ridge Volcanic Member (new name; CJES-2017-0176suppla) of the Hopewell Cape Formation (Fig. 2). A 2.5 m interval of felsic tuff occurs near the base of the volcanic succession at Hardwood Ridge (Fig. 3, locality 11), which is yet to be found at other localities, but the bulk of the Hardwood Ridge Volcanic Member is characterized by basaltic intervals of varying thicknesses separated by thinner red bed intervals (Fig. 3).

Evidence of calcretization in the higher part of the Hardwood Ridge Volcanic Member in the Killarney \#3 Borehole suggests that the top of this member may be time-equivalent to the heavily calcretized Dorchester Cape Member (Brigantian) of the Hopewell Cape Formation (Fig. 2). Based on the absence of grey bed intervals at all studied localities, remnants of the volcanic member do not seem to extend into the time interval corresponding to that of the Shepody and 
Hastings formations (Fig. 2), which are uppermost Brigantian to Pendleian based on their spore assemblages (Jutras et al., 2015).

\section{Stratigraphy of upper Mississippian units in the Magdalen Islands of eastern Quebec}

Upper Mississippian rocks on the Magdalen Islands of eastern Quebec occur as cap rocks on top of salt diapirs that are cutting through Pennsylvanian to Permian strata (Barr et al., 1985).

\section{Middle Windsor Group volcanic rocks}

La Flèche et al. (1998) demonstrated that Mississippian volcanic rocks of the Cap Adèle Member of the Hâvre aux Maisons Formation in the Magdalen Islands include both alkali and sub-alkaline basalts, but did not provide a stratigraphic context for them. Subsequent work by Giles (2008) clarified some aspects of their stratigraphic setting, constraining them to the upper Asbian Middle Windsor Group based on the biostratigraphy of minor marine sedimentary intervals (Fig. 2). This author informally sub-divided the basalt occurrences into "lower" and "upper" successions, but the stratigraphic position of alkali versus sub-alkaline basalts remains to be determined. 


\section{Analytical methods and results}

\section{Geochemistry of the upper Mississippian volcanic rocks}

\section{Analytical methods}

Fifteen volcanic rock samples collected from the Royal Road, Boiestown/Astle, Hardwood Ridge and Queenstown sections of central New Brunswick (Fig. 3, localities 6, 9, 11 and 16) were analyzed by X-ray fluorescence (major and selected trace elements in Table 1; Xray diffraction analyses of these samples are also available in CJES-2017-0176supplb, and additional XRF data are available in CJES-2017-0176supplc). The least altered samples were also analysed by ICP-MS for trace element abundances (selected elements in Table 2; supplementary data in CJES-2017-0176suppld). These data were then plotted along with geochemical data from penecontemporaneous felsic rocks of the Cumberland Hill Formation (Gray et al., 2010) and mafic rocks of the Hâvre-aux-Maisons Formation on Magdalen Islands (La Flèche et al., 1998) (Figs. 4-8). Table 2 also includes ICP-MS data from five samples collected from felsic rock boulders near the base of the Hardwood Ridge section (samples HRFB 1-5).

\section{Results}

The upper Mississippian basalts of central New Brunswick plot as alkali basalts (trachybasalts sensu Le Bas et al., 1986) on the $\mathrm{SiO}_{2}$ vs Nb/Y diagram of Winchester and Floyd (1977; Fig. 4), as well as on the $\mathrm{SiO}_{2}$ vs $\mathrm{K}_{2} \mathrm{O}+\mathrm{Na}_{2} \mathrm{O}$ diagram of Le Bas et al. (1986; Fig. 5). This suggests an enriched mantle source that experienced a low degree of partial melting at pressures exceeding $1 \mathrm{GPa}$ (Jaques and Green, 1980; Kushiro, 2001). They are similar to the average 
composition of alkali basalts on Magdalen Islands, whereas the average sub-alkaline basalt at the latter locality plots quite close to the alkali basalt (trachybasalt) range in these diagrams. At both localities, the alkali basalts are significantly enriched in light rare earth elements (LREE; Fig. 6), which also suggests a low degree of partial melting (Cullers and Graf, 1984).

The alkali basalts of central New Brunswick and the Magdalen Islands have similar trace element distribution patterns that resemble those of the average ocean island basalt as defined by Sun and McDonough (1989) (Fig. 6). For both volcanic suites, this suggests an enriched mantle source that was not significantly modified by subduction imprint or other forms of crustal contamination. This is also supported by their $\mathrm{Th} / \mathrm{Yb}$ and $\mathrm{Nb} / \mathrm{Yb}$ ratios, which plot within the enriched mantle array (Fig. 7).

On average, the alkali basalts of New Brunswick are more enriched in incompatible elements and therefore more differentiated than those of the Magdalen Islands (Fig. 6). Moreover, although the lack of negative Eu anomalies precludes a strong contribution of feldspar fractionation, much larger $\mathrm{FeO} / \mathrm{MgO}$ ratios in the alkali basalts of New Brunswick (average $=5.14)$ than in those of the Magdalen Islands (average $=1.2$ ) suggest that crystal fractionation of ferro-magnesian minerals was at play, and that it was more prolonged in the magmatic source of the former.

In the $\mathrm{Ti} / \mathrm{Y}$ vs Nb/Y diagram of Pearce (1982; Fig. 8), all mafic rocks plot on average as within-plate basalts, which is consistent with their association with continental red beds and epicontinental sea deposits. The sub-alkaline basalts of the Magdalen Islands have more primitive compositions that are closer to those of mid-oceanic ridge basalts. 


\section{U-Pb Geochronology}

\section{Studied samples}

$\mathrm{U}-\mathrm{Pb}$ zircon geochronology was carried out on three samples of volcanic material from the Hardwood Ridge section (Fig. 3; Table 3). One sample (HRFB5) is from a boulder of felsic volcanic rocks within red conglomerate of the Shin Member near the base of the exposed section, whereas the two others (samples HRLT and HRVT) were collected, from a $\sim 2.5 \mathrm{~m}$ thick succession of felsic tuff layers that occurs near the base of the conformably overlying Hardwood Ridge Volcanic Member. A sample of fine felsic tuff (Sample HRFT) from the base of the $\sim 2.5 \mathrm{~m}$ thick pyroclastic succession was also processed but only provided zircons that are clearly detrital. Sample HRLT (a slightly coarser lithic tuff) is from $\sim 0.5 \mathrm{~m}$ above and includes sand-size clastic minerals and lithic fragments floating in a fine matrix of volcanic ash that comprises $\sim 70 \%$ of the volume. Sample HRvT was collected $\sim 1 \mathrm{~m}$ above HRLT in a $\sim 1.5 \mathrm{~m}$ thick layer of coarser, vitric tuff that tops the thin pyroclastic succession.

\section{Analytical methods}

Samples were analysed by isotope dilution thermal ionization mass spectrometry (ID TIMS) at the Jack Satterly Geochronology Laboratory in the Department of Earth Sciences of the University of Toronto (Table 3). A detailed description of the analytical methods is provided in CJES-2017-0176supple. 


\section{Results on the felsic boulder (sample HRFB5)}

Four zircon grains (4-sided elongate crystals) from the large boulder of felsic volcanic rock (sample HRFB5) gave concordant data. Three (Z2-4) gave data that partially overlap and have a weighted mean ${ }^{206} \mathrm{~Pb} /{ }^{238} \mathrm{U}$ date of $368.7 \pm 1.3 \mathrm{Ma}(\mathrm{MSWD}=5.6)$ (Fig. 9). The relatively high MSWD indicates scatter that may be attributable to geological sources (e.g., the youngest grain at $368.35 \pm 0.34 \mathrm{Ma}$ only partially overlaps the 2 others and could have undergone minor $\mathrm{Pb}$ loss, or alternatively, it more closely approximates the true age of the volcanic unit and the two overlapping slightly older grains are inherited). One grain (Z1) is distinctly older than the other three, with a ${ }^{206} \mathrm{~Pb} /{ }^{238} \mathrm{U}$ age of $371.3 \pm 0.5 \mathrm{Ma}$. It is interpreted as inherited from reworked remnants of an earlier eruption. A conservative age estimate for the felsic volcanic boulder is $368.7 \pm 1.3 \mathrm{Ma}$ (Table 3). The age of this boulder corresponds well with the Upper Devonian Piskahegan Group, which is well-exposed at the southern margin of the Central-Marysville Basin (NBDNRE, 2000). Its relatively low contents in incompatible trace elements (Table 2) is also consistent with felsic igneous rocks of this unit (Yang et al., 2003).

\section{Results on the felsic tuff layers (samples HRLTand HRVT)}

Four euhedral zircon tips from sample HRLT gave three partially overlapping data that have a weighted mean ${ }^{206} \mathrm{~Pb} /{ }^{238} \mathrm{U}$ date of $335.4 \pm 1.1 \mathrm{Ma}(\mathrm{MSWD}=5.5)$ (Fig. 9). Scatter may be due to geological reasons ( $\mathrm{Pb}$ loss or inheritance). One zircon $(\mathrm{Z1})$ is slightly older at $336.83 \pm$ $0.49 \mathrm{Ma}($ Table 3).

Four zircon grains from the coarser, vitric tuff layer (HRVT) gave concordant data with a range of ages from $621.3 \pm 0.7 \mathrm{Ma}, 335.6 \pm 0.4 \mathrm{Ma}, 334.6 \pm 0.2 \mathrm{Ma}$, to $327.7 \pm 0.9 \mathrm{Ma}$ (Table 3). The latter age of $327.7 \pm 0.9 \mathrm{Ma}$ from $\mathrm{Z} 4$ is interpreted as a maximum age for deposition of 
the pyroclastic interval, whereas the $\sim 621, \sim 335$ and $\sim 337$ Ma zircons are considered to be inherited.

\section{Geophysics}

By combining available gravity, magnetic and seismic data from the Central-Marysville Basin area with field and well data, Jutras et al. (2007a) identified a series of SW-NE trending faults that offset the base of the Mississippian succession in steps that are overall increasing in depth towards the northwest until reaching the Bathurst Horst (Fig.1), which separates the Central-Marysville Basin from the Ristigouche Basin of northern New Brunswick and eastern Quebec. The Mississippian structures are overlapped by Pennsylvanian strata, which are not offset by the faults and show consistent thickness across them (Jutras et al., 2007a).

This step-like offset of basement rocks and overlying Mississippian strata along SW-NE trending fault blocks is well represented in the vertical gradient magnetic image of Kiss et al. (2004), where a zone of steep vertical gradient readings (the Chipman-Minto Block) is sharply separated from a zone of low variation in vertical gradient readings (the Grand Lake Block; Fig. 11). The Hardwood Ridge volcanics are well exposed on the Chipman-Minto Block, whereas the Grand Lake Block is characterized by inliers of pre-Carboniferous basement that are in direct contact with Pennsylvanian strata (Fig. 1), suggesting that Mississippian strata are mostly absent on that block (Fig. 11). This is also suggested by the absence of Mississippian strata between basement and Pennsylvanian rocks in the Coal Branch Borehole \#1 (Jutras et al., 2007a), which is located in the NE extension of that block. 
The Grand Lake Block is also cut by NW-SE trending lineaments of steep magnetic readings, which are interpreted as feeder dykes to the upper Mississippian lavas. It is most likely a similar dyke that forms what Bailey (1910) described as a volcanic neck of upper Mississippian mafic rocks at Currie Mountain, near Fredericton. On the Grand Lake Block, these large dykes were later truncated by post-Mississippian uplift and erosion, which Jutras et al. (2007a) correlated with the early Pennsylvanian onset of Alleghanian far-field stresses in eastern Canada.

A Pennsylvanian fault showing evidence for significant vertical displacement also limits the Chipman-Minto Block from the Fredericton Block to the northwest, which shows much flatter vertical gradient magnetic readings (Fig. 11). Based on well data, the Mississippian succession is interpreted to be substantially thicker on the latter block, which lines-up with the Fredericton Trough of van de Poll (1967). For instance, the Mississippian succession in that trough is over $\sim 350 \mathrm{~m}$ thick in the Killarney \#3 Borehole (Figure 3), and well data suggest a gradual thickening of remnant Mississippian strata towards the east (Jutras et al., 2007a). Therefore, we infer that Mississippian volcanic rocks are present on the Fredericton Block, but covered by additional sedimentary strata that dilute the vertical gradient readings (Fig. 11).

Although the Grand Lake Block is mostly devoid of Mississippian strata, it includes a small inlier of the Cumberland Hill Formation, which forms a well-defined and laterally constrained magnetic anomaly (Fig. 11) that we interpret to represent a residual hill of Mississippian rocks in the process of being exhumed from its Pennsylvanian cover (Fig. 14). Although exposed remnants of the Cumberland Hill Formation are only known from the Cumberland Hill area, Thomas and Kiss (2005) identified an unexposed area on the ChipmanMinto Block that bears a similar magnetic signature as the Cumberland Hill volcanics (circular dashed line on Figure 11). As it truncates the more complex magnetic signature that is attributed 
to the Hardwood Ridge basalts, it possibly represents another residual hill of the Cumberland Hill Formation that was subsequently buried by the Hopewell Cape Formation.

Thomas and Kiss (2005) also identified two igneous plugs (solid, circular lines on Figure 11) on the Chipman-Minto Block that could have acted as feeder pipes for Mississippian volcanism. These authors attribute irregular lineaments in the southeast portion of the Grand Lake Block to pre-Carboniferous basement features (Fig. 11).

\section{Provenance of the Shin Member of the Hopewell Cape Formation}

To identify active faults controlling late Mississippian sedimentation and volcanism in central New Brunswick, five paleocurrent localities were added to the three paleocurrent localities of Jutras et al. (2007a) from the north part of the Central-Marysville Basin, all from the Shin Member of the Hopewell Cape Formation (Fig. 10). Measurements from trough channel orientations were obtained at all localities (Fig. 10). Where an insufficient number of these could be retrieved, the scour-and-fill data were combined with less reliable but in this case corroborating clast imbrication data (Fig. 10).

Based on paleocurrent vectors, facies distribution, mapping data and inferences from nearby basins, Jutras et al. (2007a) concluded that the Shin Member of the Hopewell Cape (then Bonaventure) Formation in the north part of the Central-Marysville Basin was sourced from a reverse fault scarp developed along the SW-striking Miramichi Fault complex, which separates the basin from the Miramichi Highlands, and a dextral transtensional fault scarp developed along the E-W striking Heath Steele Fault, which separates the basin from the Bathurst Horst. Based on paleocurrent vectors obtained along the Sevogle River (Fig. 10, locality 1), the Sevogle Fault 
may have been active at the time as a normal fault. New data from South Tay Creek (locality 7), Mactaquac Dam (locality 8) and Finger Lakes (locality 13) suggest that the Miramichi Highlands source area, bounded by the Miramichi Fault, extended farther to the southwest than the Fredericton area, which implies that the Fredericton Fault is a post-Mississippian structure (Fig. 10). This undermines the distinction between the Marysville and Central basins of van de Poll (1995), which correspond respectively to the southern and northern areas of the same Mississippian basin, herein referred to as the Central-Marysville Basin.

Additional data from the Shin Creek (locality 14) and Shannon (locality 20) sections suggest that the Kingston Uplift of St. Peter and Johnson (2009) formed the southeast boundary of the Central-Marysville Basin, bounded by the Belleisle Fault (Fig. 10). This is also supported by the abundance of Precambrian schist clasts in the coarse Shin Member at Shannon, a lithology that is present in the Kingston Uplift, but not in the Miramichi Highlands (NBDNRE, 2000). Identification of the Bathurst Horst, Miramichi Highlands and Kingston Uplift as source areas of the Central-Marysville Basin is also supported by the coarseness of the Hopewell Cape Formation sediments in their vicinity (sections 1-4, 6-9 and 13-20 on Figure 1).

Paleocurrents were also obtained from about halfway between the Miramichi Highlands and the Kingston Uplift, at Hardwood Ridge (locality 11), where NE-driven paleocurrents in broad channel-fills are inferred to represent a trunk river system. Oversized boulders of phyllite, phreatic calcrete and felsic volcanic rocks dated at 368.7 $\pm 1.3 \mathrm{Ma}$ (sample HRFB5) near the unexposed base of the succession are interpreted as rock fall boulders issued from an irregular basin floor. They suggest deposition in a paleovalley cutting through remnants of the La Coulée Calcrete above volcanic rocks of the Piskahegan Group and Silurian basement rocks of the Kingsclear Group (Fig. 3), all of which are observed unconformably below the Hopewell Cape 
Formation in exposed sections and wells of southern areas of the Central-Marysville Basin (Fig. $1)$.

\section{General discussion and conclusions}

\section{Biostratigraphy versus geochronology}

Based on the timescale of Richards (2013), the $\sim 328$ Ma Hardwood Ridge volcanic rocks are lower Pendleian at the oldest. However, based on field relationships and regional biostratigraphic constraints from Utting and Giles (2004) and von Bitter et al. (2007), they would be upper Asbian at the oldest, or Brigantian at the youngest. The new isotopic dates therefore reveal some significant discrepancies between biostratigraphic substage subdivisions for the Visean to Serpukhovian interval of eastern Canada and the timescale proposed by Richards (2013). The latter is largely based on dates obtained from Asia, whereas the biostratigraphy of eastern Canada is based on correlations with Europe, which might be one of the causes for the discrepancy. Moreover, it should be noted that absolute age estimations for these volcanic rocks and for Visean to Pendleian substage subdivisions are based on isotopic dates with error ranges estimated between ${ }^{ \pm} 1$ and ${ }^{ \pm} 6$ My (Menning et al., 2000, 2006; Davydov et al., 2012; Richards, 2013). For this reason, estimation of Visean to Pendleian substage boundaries has varied greatly over the years, with the Holkerian-Asbian, Asbian-Brigantian and Brigantian-Pendleian boundaries increasing in age by respectively $\sim 6, \sim 4.5$ and $~ 2$ My between Menning et al. (2000) and Richards (2013). In this context of a quite imprecise and still evolving timescale that might require some reconciliation between biostratigraphic data from eastern Canada, Europe and Asia, we favour the scale of Menning et al. (2006), which was built by a consortium of 20 researchers, 
and which correlates better with biostratigraphic constraints (Fig. 2). Based on that scale, the Hardwood Ridge Volcanic Member is upper Brigantian, which suggests that it is younger than the upper Asbian Magdalen Island basalts. (Fig. 2). However, considering the uncertainty of correlations between isotopic and biostratigraphic ages, we do not rule out the possibility that these units could be in part coeval.

\section{Tectonostratigraphic setting of central New Brunswick in late Mississippian times}

In the Ristigouche Basin of northern New Brunswick and eastern Quebec, it was determined that coarse clastics of the mid-Visean La Coulée Formation, which locally host the syn-depositional La Coulée Calcrete, were sourced from fault scarps developed in response to NW-SE shortening (Jutras and Prichonnet, 2005). A similar tectonic setting is inferred for the time-equivalent Lower Windsor Group in central New Brunswick (Jutras et al., 2007b).

\section{Cumberland Hill Formation}

Based on available data, the Cumberland Hill Formation is estimated to be at least 7 My older than the Hardwood Ridge Volcanic Member, unlike the conclusions of the NBDNRE (2010), which considered the two units to be coeval. As it is absent below the upper Asbian to Brigantian Hopewell Cape Formation (sensu Jutras et al., 2016) at all localities (Fig. 1), the Cumberland Hill Formation may have been affected by the same erosion event that eradicated most of the Holkerian Lower Windsor Group and La Coulée Calcrete in central New Brunswick (Jutras et al., 2007b). The product of this erosion is inferred to be the Tennycape Formation (sensu Jutras et al., 2016), which was sourced and accommodated by gentle SW-NE trending crustal flexures that are also interpreted to be a response to NW-SE shortening (Jutras and 
Prichonnet, 2005; Jutras et al., 2007a, b), but during a slowdown of shortening rates (Jutras, 2014).

The broad anticlinal flexures that sourced the Tennycape Formation may have provided a setting where highly differentiated residual fluids could be concentrated and where a volcanic breach could easily occur in the anticlinal hinge zones. The igneous plugs identified by Thomas and Kiss (2005) on the Chipman-Minto Block (Fig. 11) may have been the sites of such breaches of felsic magma. Hence, we interpret the Cumberland Hill lavas as possibly syn-depositional to the Tennycape Formation and occurring in the source area of the latter.

\section{Hopewell Cape Formation}

As NW-SE shortening rates re-increased, fault-controlled sedimentation resumed with deposition of the Hopewell Cape Formation (ex-Bonaventure Formation) (Jutras and Prichonnet, 2005). In this context, we infer dextral movement with a normal component along the E-W striking Heath Steele Fault, normal movement along the NW-SE striking Sevogle Fault, reverse movement along the SW to WSW striking Miramichi Fault, and reverse movement with a dextral component along the NE to ENE striking Belleisle Fault (Fig. 13). As noted earlier, syndepositional scarp development along these faults is suggested by the distribution of coarse facies and paleocurrent vectors in the Shin Member (Figs. 1, 3, 10 and 13). It is in association with these faults that the large NW-SE trending dykes (Fig. 11) are interpreted to have developed as a pull-apart response to NW-SE shortening in a transtensional to compressional graben complex, thus sourcing basalts of the overlying Hardwood Ridge Volcanic Member. In this context, the dykes would have developed from extension perpendicular to the main principal stress, which is consistent with previous studies suggesting that mid- to late Mississippian 
tectonics in the Maritimes Basin were controlled by NW-SE shortening (Jutras and Prichonnet, 2005; Wilson and White, 2006; Jutras et al., 2005, 2007a, 2015, 2016).

\section{Petrogenetic and emplacement models for the upper Mississippian volcanic rocks of eastern Canada}

Based on their $\varepsilon N d$ value of +3 (Pe-Piper and Piper, $1998 ;+3.40$ and +4.26 in Dostal and Jutras, 2016), the absence of negative $\mathrm{Nb}$ anomalies, and a high content in incompatible elements, Gray et al. (2010) concluded that trachyte of the Cumberland Hill Formation evolved from the prolonged crystal fractionation of alkali magma derived from an asthenospheric source that experienced a low degree of partial melting. A similar scenario is inferred for the Hardwood Ridge Volcanic Member, which hosts compositionally similar tuff and which is interpreted to have evolved from the same primary source. However, their significant age difference suggests that they are the products of two distinct magmatic pulses.

Geochemical similarities between penecontemporaneous alkali basalts from the upper Mississippian successions of the Magdalen Islands and central New Brunswick suggest that they are correlative and have a common petrogenetic history. On the Magdalen Islands, La Flèche et al. (1998) dismissed the possibility of a common source for the sub-alkaline and alkali basalts of that succession based on the wide distribution of $\varepsilon_{\mathrm{Nd}}$ values, which range from +2.0 to +7.0 . However, when only alkali basalts are considered, these values are still widely distributed between +2.0 to +6.3 (La Flèche et al., 1998). Moreover, the sub-alkaline basalts are also relatively rich in incompatible elements and on average quite close to the range of alkali basalts (Figs. 4 and 5). La Flèche et al. (1998) subdivided them based on the $\mathrm{Zr} / \mathrm{TiO}_{2}$ vs $\mathrm{Ta} / \mathrm{Y}$ classification diagram of Floyd and Winchester (1978), but also noted that their 51 samples show 
a widespread and rather continuous distribution from one range to the other. In all their other geochemical diagrams, both types of basalts also show a continuous distribution and a partly overlapping range. We therefore conclude that invoking two different sources is unnecessary and that different degrees of partial melting possibly combined with different degrees of crystal fractionation may explain all the variations.

As noted by La Flèche et al. (1998), high $\mathrm{AlO}_{2} / \mathrm{TiO}_{2}$ ratios in the Magdalen Island basalts, which are comparable in the penecontemporaneous New Brunswick occurrences (Table $1)$, suggest that they were differentiated under high pressure ( $\sim 10 \mathrm{kbar})$. Hence, crystal fractionation may have occurred at the base of the crust beneath the Maritimes Basin, where a 10 to $20 \mathrm{~km}$ thick mafic underplating has been inferred from a combination of gravity and deep seismic data (Marillier and Verhoef, 1989). It is likely that this mafic underplating contributed to magmatism in the Maritimes Basin since its opening, in Late Devonian times (Pe-Piper and Piper, 1998). Early magmatism (Late Devonian to Tournaisian) was dominantly sub-alkaline and its isotopic signature is mostly compatible with a lithospheric mantle source that has been enriched by subduction, which occurred at the eastern North American margin through most of the early to middle Paleozoic (Pe-Piper and Piper, 1998). However, the upper Mississippian volcanic rocks of New Brunswick and eastern Quebec do not show evidence for contamination by subduction, and they include trace element abundances that are quite similar to those of ocean island basalts. It therefore seems that, contrary to the conclusions of La Flèche et al. (1998), late magmatism in the Maritimes Basin was no longer fed by the contaminated lithospheric mantle, but rather by partial melting of the sub-lithospheric mantle.

Our proposed model is that transtensional lithospheric stretching in the Maritimes Basin first contributed to a high degree of partial melting at the base of a metasomatically enriched 
lithosphere, with the rising melts accumulating at the base of the crust throughout the lateral extent of the Maritimes Basin. As pull-apart transtensional tectonics characterized most of the Late Devonian to Early Carboniferous interval (Hibbard and Waldron, 2009), it is likely that this 10 to $20 \mathrm{~km}$ thick accumulation of mafic material occurred gradually, in pulses. Available data suggest that melts evolved from a sub-continental lithospheric primary source with a high degree of partial melting, in early stages, to a sub-lithospheric primary source with a low degree of partial melting, in late stages.

Inputs of alkali mafic magma in the mafic underplating body at the base of the crust may have started in response to mid-Visean transtensional faulting, followed by a long period of crystal fractionation and the development of highly differentiated felsic magma at the top of the magmatic body. The latter may have subsequently concentrated in some of the broad anticlinal folds that sourced the mid-Visean Tennycape Formation, eventually breaching through one of these folds to source the Cumberland Formation, southeast of the Fredericton Trough.

Reactivation of the faults that controlled deposition of the Middle Windsor Group and Hopewell Cape Formation may have generated new inputs of alkali magma at the base of the crust in late Asbian times, followed by a new period of crystal fractionation. The thin layers of felsic tuff near the base of the Hardwood Ridge Volcanic Member are inferred to be the products of explosive extrusions of highly differentiated residual fluids from the top of the evolving magma chamber that also sourced the overlying alkali basalts. As this tuff includes many inherited zircons of the same age as those in rhyolite of the Cumberland Hill Formation, the two felsic units were possibly sourced from the same discrete volcanic area. In contrast, as noted earlier, subsequent mafic lavas were seemingly fed by large NW-SE trending dykes such as those observable on Figure 11 in response to the ongoing NW-SE shortening that is inferred to 
have controlled Mississippian tectonics in the area (Jutras and Prichonnet, 2005; Wilson and White, 2006; Jutras et al., 2005, 2007a, 2015, 2016).

The penecontemporaneous Hardwood Ridge and Magdalen Islands basalts were possibly all fed by pull-apart openings along the Belleisle Fault (Fig. 14), one the most extensive structures of eastern North America (Hibbard and Waldron, 2009), but as Mississippian strata are deeply buried below Pennsylvanian to Permian strata in the Gulf of Saint-Lawrence, it is at this stage impossible to determine whether or not basalts of central New Brunswick and of the Magdalen Islands are part of the same Mississippian structural basin. However, the apparent absence of sub-alkaline lavas in the Central-Marysville Basin suggests that individual lava flows did not cover both areas, which is also suggested by basaltic bodies that are insufficiently thick to represent large scale flood basalts.

\section{Acknowledgements}

We wish to thank the Natural Sciences and Engineering Research Council of Canada for financial support, R. Corney for the making of thin-sections, and C. Lewis for help with sample preparation and thin-section analysis. We also thank J.B. Mahoney and Associate Editor K. Russell for constructive reviews, as well as Editor A. Polat for handling of our manuscript. 


\section{References}

Anderson, F.D., and Poole, W.H. 1959. Geology, Woodstock-Frederiction; York, Carleton, Sunbury and Northumberland counties, New Brunswick. Geological Survey of Canada Map 37-1959.

Bailey, L.W. 1910. The history of Curries Mountain - an old New Brunswick volcano. Natural History Society of New Brunswick, Bulletin 6, No. 28, pp. 189-197.

Barr, S.M., Brisebois, D., and Macdonald, A.S. 1985. Carboniferous volcanic rocks of the Magdalen Islands, Gulf of St. Lawrence. Canadian Journal of Earth Sciences 22: 1679-1688.

Brisebois, D. 1981. Lithostratigraphie des strates Permo-Carbonifères de l'archipel des îles de la Madeleine. Ministère de l'Énergie et des Ressources du Québec, 48 p.

Cullers, R.L., and Graf, J.L. 1984. Rare earth elements in igneous rocks of the continental crust: predominantly basic and ultrabasic rocks. In Rare earth element geochemistry, Edited by P. Henderson. Elsevier, Amsterdam, pp. 237-274.

Davydov, V.I., Korn, D., and Schmitz, M.D. 2012. The Carboniferous Period. In The Geologic Time Scale. Edited by F.M. Gradstein, J.G. Ogg, M.D. Schmitz, and G.M. Ogg. Elsevier, Amsterdam, pp. 603-651.

Dostal, J., and Jutras, P. 2016. Upper Paleozoic mafic and intermediate volcanic rocks of the Mount Pleasant Caldera associated with the Sn-W deposit in southwestern New Brunswick (Canada); petrogenesis and metallogenic implications. Lithos 262: 428-441.

Floyd, P.A., and Winchester, J.A. 1978. Identification and discrimination of altered and metamorphosed volcanic rocks using immobile elements. Chemical Geology 21: 291-306.

Freeze, A.C. 1936. Geology of the Fredericton Sheet, New Brunswick: M.Sc. Thesis, University of New Brunswick, Fredericton, 64 p. 
Fyffe, L.R., and Barr, S.M. 1986. Petrochemistry and tectonic significance of Carboniferous volcanic rocks in New Brunswick. Canadian Journal of Earth Sciences 23: 1243-1256.

Gibling, M.R., Culshaw, N., Rygel, M.C., and Pascucci, V. 2008. The Maritimes Basin of Atlantic Canada: Basin Creation and Destruction in the Collisional Zone of Pangea. In Sedimentary Basins of the World, Vol. 5. Edited by A.D. Miall, pp. 211-244.

Giles, P.S. 2008. Windsor Group (Late Mississippian) stratigraphy, Magdalen Islands, Quebec: a rare eastern Canadian record of late Visean basaltic volcanism. Atlantic Geology 44: 167185.

Gray, T.R, Dostal, J., McLeod, M., Keppie, D., and Zhang, Y. 2010. Geochemistry of Carboniferous peralkaline felsic volcanic rocks, central New Brunswick, Canada; examination of uranium potential. Atlantic Geology 46: 173-184.

Hibbard, J., and Waldron, J.W.F. 2009. Truncation and translation of Appalachian promontories: Mid-Paleozoic strike-slip tectonics and basin initiation. Geology 37: 487-490; doi: 10.1130/G25614A.1.

Jaques, A.L., and Green, D.H. 1980. Anhydrous melting of peridotite at $0-15 \mathrm{~kb}$ pressure and the genesis of tholeiitic basalts. Contributions to Mineralogy and Petrology 73: 287-310.

Jutras, P. 2014. Sedimentation in broad crustal flexures in response to the slowdown of an ongoing NW-shortening trend during the Holkerian and the early Asbian (mid-Viséan) in Atlantic Canada. Geological Association of Canada/Mineral Association of Canada, Joint Annual Meeting, Fredericton 2014, Session SS13: Sedimentary Signatures of Tectonic Events.

Jutras, P., and Prichonnet, G. 2002. Stratigraphy, depositional setting and diagenetic history of the Saint-Jules Formation (Upper Devonian or Mississippian), a newly identified post- 
Acadian red clastic unit in the southern Gaspé Peninsula, Québec. Canadian Journal of Earth Sciences 39: 1541-1551.

Jutras, P., and Prichonnet, G. 2005. Record of Late Mississippian tectonics in the new Percé Group (Viséan) of eastern Gaspésie, Quebec. Canadian Journal of Earth Sciences 42: 815832.

Jutras, P., Prichonnet, G., and von Bitter, P. 1999. The La Coulée Formation, a new postAcadian continental clastic unit bearing groundwater calcretes, Gaspé Peninsula, Québec. Atlantic Geology 35: 139-156.

Jutras, P., Prichonnet, G. and Utting, J. 2001. Newly identified Carboniferous units (The Pointe Sawyer and Chemin-des-Pêcheurs formations) in the Gaspé Peninsula, Québec; Implications regarding the evolution of the northwestern sector of the Maritimes Basin. Canadian Journal of Earth Sciences 38: 1-19.

Jutras, P., Utting, J., and McCutcheon, S. 2005. Basin inversion at the MississippianPennsylvanian boundary in northern New Brunswick. Bulletin of Canadian Petroleum Geology 53: 390-404.

Jutras, P., MacRae, A., and Utting, J. 2007a. Viséan tectonostratigraphy and basin architecture beneath the Pennsylvanian New Brunswick Platform of eastern Canada. Bulletin of Canadian Petroleum Geology 55: 217-236.

Jutras, P., Utting, J., and McLeod, J. 2007b. Link between long-lasting evaporitic basins and the development of thick and massive phreatic calcrete hardpans in the Mississippian Windsor and Percé groups of eastern Canada. Sedimentary Geology 201: 75-92.

Jutras, P., McLeod, J., and Utting, J. 2015. Sedimentology of the lower Serpukhovian (upper Mississippian) Mabou Group in the Cumberland Basin of eastern Canada; tectonic, 
halokinetic and climatic implications. Canadian Journal of Earth Sciences 52: 1150-1168, doi: 10.1139/cjes-2015-0062.

Jutras, P., McLeod, J., MacRae, R.A., and Utting, J. 2016. Complex interplay of faulting, glacioeustatic variations and halokinesis during deposition of upper Viséan units over thick evaporites in the western Cumberland Basin of Atlantic Canada. Basin Research 28: 483506, doi: 10.1111/bre.12119.

Kiss, F., Potvin, J., and Coyle, M. 2004. Shaded Magnetic First Derivative, Chipman, New Brunswick (NTS 21 I/04); Geological Survey of Canada, Open File 4651, New Brunswick Department of Natural Resources, Minerals, Policy and Planning Division, Plate 2004-11A, Scale 1:50 000.

Kushiro, I. 2001. Partial melting experiments on peridotite and origin of mid-ocean ridge basalt. Annual Review of Earth and Planetary Sciences 29: 71-107.

La Flèche, M.R., Camire, G., and Jenner, G.A. 1998. Geochemistry of post-Acadian, Carboniferous continental intraplate basalts from the Maritimes Basin, Magdalen Islands, Quebec, Canada. Chemical Geology 148: 115-136.

Le Bas, M.J., Le Maitre, R.W, Streckeisen, A., and Zanettin, B.A. 1986. Chemical classification of volcanic rocks based on the total alkali-silica diagram. Journal of Petrology 27: 745-750.

MacKenzie, G.S. 1964. Geology of Hampstead, New Brunswick. Geological Survey of Canada, Map 1114A.

Marillier, F., and Verhoef, J. 1989. Crustal thickness under the Gulf of St. Lawrence, Northern Appalachians, from gravity and deep seismic data. Canadian Journal of Earth Sciences 26: 1517-1532. 
McCutcheon, S.R. 1981. Stratigraphy and paleogeography of the Windsor Group in Southern New Brunswick. MSc Thesis, Acadia University, Wolfville, Nova Scotia, Canada. McLeod, M.J., and Johnson, S.C. 1998. Bedrock geological compilation of the Fredericton area (NTS 21 G/15), York and Sunbury counties, New Brunswick. New Brunswick Department of Natural Resources and Energy, Minerals and Energy Division, Plate 98-33.

Menning, M., Alekseev, A.S., Chuvashov, B.I., Davydov, V.I., and Devuyst, F.X., et al. 2006.

Global time scale and regional stratigraphic reference scales of central and west Europe, east Europe, Tethys, south China, and North America as used in the Devonian-CarboniferousPermian Correlation Chart 2003 (DCP 2003). Palaeogeography, Palaeoclimatology, Palaeoecology 240: 318-372.

Menning, M., Weyer, D., Drozdzewski, G., Van Amerom, H.W.J., and Wendt, I. 2000. A Carboniferous timescale 2000: Discussion and use of geological parameters as time indicators from central and western Europe. Geologisches Jahrbuch A156: 3-44.

Muller, J.E. 1951. Geology and coal deposits of Minto and Chipman map-areas, New Brunswick. Geological Survey of Canada, Memoir 260, 40 p.

New Brunswick Department of Natural Resources and Energy 2000. Bedrock geology of New Brunswick. Minerals and Energy Division, Map NR-1 (2000 Edition). Scale 1:500 000.

New Brunswick Department of Natural Resources and Energy (NBDNRE) 2010. Bedrock lexicon of the New Brunswick Minerals and Energy Division. URL <http://www1.gnb.ca/0078/GeoscienceDatabase/Lexicon/qryFormationSummarye.asp?UnitId=251>, April 2010, New Brunswick. 
Pearce, J.A. 1982, Trace element characteristics of lavas from destructive plate boundaries. In Andesites: Orogenic Andesites and Related Rocks. Edited by R.S. Thorp, John Wiley and Sons, New York, pp. 525-548.

Pearce, J.A., 2008. Geochemical fingerprinting of oceanic basalts with applications to ophiolite classification and the search for Archean oceanic crust. Lithos 100: 14-48.

Pe-Piper, G., and Piper, D.J.W. 1998. Geochemical evolution of Devonian-Carboniferous igneous rocks of the Magdalen Basin, Eastern Canada; $\mathrm{Pb}$ - and $\mathrm{Nd}$-isotope evidence for mantle and lower crustal sources. Canadian Journal of Earth Sciences 35: 201-221.

Poole, W.H., 1958. Napadogan, York County, New Brunswick, Geological Survey of Canada, Map 11-1958.

Richards, B.C. 2013. Current status of the International Carboniferous Time Scale. In The Carboniferous-Permian Transition, Bulletin 60. Edited by S.G. Lucas et al., New Mexico Museum of Natural History and Science, pp. 348-353.

St. Peter, C.J. 2000. Carboniferous geology of the southwestern New Brunswick Platform (Marysville Subbasin). New Brunswick Department of Natural Resources and Energy, Minerals and Energy Division, Plate 2000-16.

St. Peter, C. J. 1997. Bedrock geology of Chipman - Canaan River map area (parts of NTS 21 I/04 and 21 H/13), Sunbury, Queens and Kings counties, New Brunswick. New Brunswick Department of Natural Resources and Energy, Mineral Resources, Plate 97-34.

St. Peter, C.J. 1979. Geology of Wapske-Odell River-Arthurette region, New Brunswick. Map areas I-13, I-14, H-14 (Parts of $21 \mathrm{~J} / 11,21 \mathrm{~J} / 12,21 \mathrm{~J} / 13,21 \mathrm{~J} / 14$ ). New Brunswick Department of Natural Resources, Mineral Resources Branch, Map Report 79-2, 32 p. 
St. Peter, C.J., and Johnson, S.C. 2009. Stratigraphy and structural history of the late Palaeozoic Maritimes Basin in southeastern New Brunswick, Canada. New Brunswick Department of Natural Resources; Minerals, Policy and Planning Division, Memoir 3.

Sun, W., and McDonough, W.F. 1989. Chemical and isotopic systematics of oceanic basalts: implications of mantle composition and processes. Journal of the Geological Society, London 42: 313-345.

Thomas, M.D., and Kiss, F. 2005. Geological interpretation of the 2004 Marrtown aeromagnetic survey, SoutheasternNew Brunswick. Geological Survey of Canada, Open File 4953, New Brunswick Department of Natural Resources, Minerals, Policy and Planning Division. Plate 2005-21D, scale 1:125000.

Utting, J. 2003. Palynological examination of 6 outcrop samples and 27 subsurface samples from the Carboniferous of New Brunswick (NTS 21I/11, 21J/2, 21J/16, 21P/4, 21P/5, 21P/11, 21P/12, 21P/13). Geological Survey of Canada (Calgary), Report 05-Ju-2003.

Utting, J., and Giles, P.S. 2004. Biostratiographical implications of new palynological data from the Mississippian of Newfoundland and Nova Scotia, Canada. Memoirs of the Association of Australasian Palaeontologists 29: 115-160.

van de Poll, H. W. 1967. Carboniferous volcanic and sedimentary rocks of the Mount Pleasant area, New Brunswick. New Brunswick Department of Natural Resources and Energy, Mineral Resources Branch, Report of Investigations 3, 52 p.

van de Poll, H. W. 1995. Upper Paleozoic rocks; New-Brunswick, Prince-Edward-Island and Îles-de-la-Madeleine. In Geology of the Appalachian / Caledonian Orogen in Canada and Greenland. Edited by H. Williams. Geological Survey of Canada, Geology of Canada, No. 6, pp. 455-492. 
von Bitter, P.H., Giles, P.S., and Utting, J. 2007. Biostratigraphic correlation of major cycles in the Windsor and Codroy groups of Nova Scotia and Newfoundland, Atlantic Canada, with the Mississippian substages of Britain and Ireland. In Proceedings of the XVth International Congress on Carboniferous and Permian Stratigraphy. Edited by T.E. Wong. Royal Netherlands Academy of Arts and Sciences, pp. 513-534.

Williams, H. 1995. Temporal and spatial divisions--Divisions temporelles et spatiales. In Geology of the Appalachian / Caledonian Orogen in Canada and Greenland. Edited by H. Williams. Geological Survey of Canada, Geology of Canada, No. 6, pp.21-44.

Wilson, P., and White, J.C. 2006. Tectonic evolution of the Moncton Basin, New Brunswick, eastern Canada: New evidence from field and subsurface data. Bulletin of Canadian Petroleum Geology 54: 319-336.

Winchester, J.A., and Floyd, P.A. 1977. Geochemical discrimination of different magma series and their differentiation products using immobile elements. Chemical Geology 20: 325-343. Yang, X.-M., Lentz, D.R., and McCutcheon, S.R. 2003. Petrochemical evolution of subvolcanic granitoid intrusions within the Late Devonian Mount Pleasant Caldera, southwestern New Brunswick, Canada: comparison of Au versus Sn-W-Mo-polymetallic mineralization systems. Atlantic Geology 39: 77-196.

Zaitlin, B.A., and Rust, B.R. 1983. A spectrum of alluvial deposits in the Lower Carboniferous Bonaventure Formation of the Western Chaleur Bay area, Gaspé and New Brunswick, Canada. Canadian Journal of Earth Sciences 20: 1098-1110. 


\section{Figure and table captions}

Table 1. Concentrations of major element oxides (from glass discs; in weight percent) and three selected trace elements (from pressed powders; in parts per million) based on X-ray fluorescence analysis using a Phillips PW2400 spectrometer (Regional Geochemical Centre of Saint Mary's University, Halifax, Canada). Samples marked with * were analyzed with inductively coupled plasma mass spectrometry (ICP-MS; detection limit of $0 . .001 \%$ for $\mathrm{MnO}$ and $\mathrm{TiO} 2$, and of $0.01 \%$ for all other major elements; detection limit of $1 \mathrm{ppm}$ for $\mathrm{Y}$ and $\mathrm{Nb}$, and $2 \mathrm{ppm}$ for $\mathrm{Zr}$ ). Note that samples RR1, Q3, B3 and HR2 were analyzed with both XRF and ICP-MS. ' : data from Gray et al. (2010); ${ }^{2}$ : Magdalen Island (MI) data from La Flèche et al. (1998). Sample localities are indicated on Figure 3: Royal Road (RR), Queenstown (Q), Boiestown/Astle (B), and Hardwood Ridge (HR).

Table 2. Selected trace element contents determined by inductively coupled plasma mass spectrometry (ICP-MS) analyses performed at Activation Laboratories, Ancaster, Ontario, Canada. ${ }^{2}$ : Magdalen Island (MI) data from La Flèche et al. (1998). Sample localities are indicated on Figure 3: Royal Road (RR), Queenstown (Q), Boiestown/Astle (B), and Hardwood Ridge (HR). NS: Nova Scotia; NB: New Brunswick; QC: Quebec.

Table 3. U-Pb isotopic data for chemically-abraded zircon grains from rocks of the upper Mississippian Hopewell Cape Formation of central New Brunswick. Each Z sample is a single zircon grain. The analytical methods are defined in CJES-2017-0176supple.

Fig. 1. Simplified geology of central New Brunswick with 20 sections showing upper Mississippian rocks beneath the Hopewell Cape Formation. The few remnant sections that reach high enough in this unit to include volcanic rocks are shown on Figure 3. Also shown (in orange) 
is the transect of cross-section ABC (Fig. 12) and the locality of the Cole Branch \#1 Borehole, where Mississippian rocks are absent between pre-Carboniferous basement rocks and Pennsylvanian strata (Jutras et al., 2007a). The localities of productive spore samples (eg., C430576) from the Geological Survey of Canada database are indicated on the sections. Inset: location of the current study area (squared) and that of Gray et al. (2010) in central New Brunswick, as well as those of La Flèche et al. (1998) and Giles (2008) on the Magdalen Islands of eastern Quebec. Locality a: Gladwyn Basalt in the Plaster Rock Basin; Locality b: Gladwyn Basalt in the Carlisle Basin.

Fig. 2. Stratigraphic table of the late Arundian to early Pendleian interval in central New Brunswick and the Magdalen Islands of eastern Quebec based on the time scale of Menning et al. (2006). $\mathrm{CH}$ Fm = Cumberland Hill Formation; HC Fm = Hopewell Cape Formation; HRV Mbr= Hardwood Ridge Volcanic Member; 1: Currie Mountain Basalt of McLeod and Johnson (1998) and Royal Road Basalt of St. Peter (2000); 2: McKinley Formation of Anderson and Poole (1959); 3: Parleeville Formation of McCutcheon (1981); 4: Queenstown Basalt of Mackenzie (1964); 5: Shin Formation of van de Poll (1967); 6: Hardwood Ridge Basalt of Muller (1951); 7: Newcastle Creek Formation of Muller (1951); 8: Boiestown Basalt of Fyffe and Barr (1986), mapped as the Royal Road Basalt by St. Peter (2000); 9: unnamed Mississippian red beds of Poole (1958), mapped as the Shin Formation by St. Peter (2000).

Fig. 3. Stratigraphy of sections 8, 11-14 (localities shown on Figure 1), where the upper Mississippian volcanic rocks of central New Brunswick are best represented. Also shown is the stratigraphic position of studied samples. The spore date from the Killarney \#3 Borehole section is from Utting (2003). 
Fig. 4. Upper Mississippian volcanic rocks of central New Brunswick and the Magdalen Islands plotted on the $\mathrm{SiO}_{2}$ vs $\mathrm{Nb} / \mathrm{Y}$ diagram of Winchester and Floyd (1977).

Fig. 5. Upper Mississippian volcanic rocks of central New Brunswick and the Magdalen Islands plotted on the $\mathrm{SiO}_{2}$ vs $\mathrm{K}_{2} \mathrm{O}+\mathrm{Na}_{2} \mathrm{O}$ diagram of Le Bas et al. (1986).

Fig. 6. Trace element abundances in the upper Mississippian basalts of central New Brunswick and those of the Magdalen Islands normalized against primitive mantle values from Sun and McDonough (1989).

Fig. 7. Upper Mississippian basalts of eastern Canada on the $\mathrm{Th} / \mathrm{Yb}$ vs $\mathrm{Nb} / \mathrm{Yb}$ plot of Pearce (2008).

Fig. 8. Upper Mississippian basalts of central New Brunswick and the Magdalen Islands plotted on the $\mathrm{Ti} / \mathrm{Y}$ vs $\mathrm{Nb} / \mathrm{Y}$ diagram of Pearce (1982).

Fig. 9. ${ }^{238} \mathrm{U} /{ }^{206} \mathrm{~Pb}$ Concordia plots for zircons retrieved from a felsic rock boulder in conglomerate of the Shin Member (sample HRFB5) and from a thin interval of felsic tuff near the base of the Hardwood Ridge Volcanic Member (samples HRvT and HRFT1-2) along Newcastle Creek (Hardwood Ridge section), New Brunswick.

Fig. 10. Paleocurrent measurements from trough channel orientations and clast imbrications in the Shin Member of the Hopewell Cape Formation.

Fig. 11. Interpretation of the first derivative magnetic gradient image of Kiss et al. (2004) for the Chipman-Minto area (shown on Figure 1). Large dashed-lines mark the interpreted position of early Pennsylvanian fault-lines; dashed and full circular lines limit areas interpreted by Thomas and Kiss (2005) to respectively represent felsic igneous rock complexes and igneous plugs. 
Fig. 12. Cross-section A-B-C (transect on Figure 1), showing the fragmented Mississippian Central-Marysville Basin below Pennsylvanian strata. Inferred stratigraphy in the Fredericton Trough is based on Jutras et al. (2007a, b).

Fig. 13. Paleogeographic reconstruction of the Shin Member of the Hopewell Cape Formation in the Central-Marysville Basin prior to the onset of Hardwood Ridge Volcanic Member volcanism, with the position of studied localities that include that unit. Note that localities located north of the Catamaran Fault (Fig. 1) were displaced to the right as this fault is inferred to have known post-Mississippian dextral displacement (Jutras et al., 2007a).

Fig. 14. Interpretation of the tectonic setting of upper Mississippian volcanic rocks in eastern Canada. 


\begin{tabular}{|c|c|c|c|c|c|c|c|c|c|c|c|c|c|c|c|c|}
\hline & ample & O.I. & $\mathrm{SiO}_{2}$ & $\mathrm{iO}_{2}$ & $\mathbf{A l}_{2} \mathbf{O}_{3}$ & $\mathrm{Fe}_{2} \mathrm{O}_{3}$ & MnO & MgO & $\mathrm{CaO}$ & $\mathrm{Na}_{2} \mathrm{O}$ & $\mathrm{K}_{2} \mathrm{O}$ & $\mathrm{P}_{2} \mathrm{O}_{5}$ & Totals & $\mathbf{Z r}$ & Nb & $\mathbf{Y}$ \\
\hline & RR3 & 2.22 & 50.02 & 437 & 15.07 & 14.47 & 0.342 & 1.90 & 4.22 & 5.23 & 2.56 & 1.84 & 100.31 & 509 & 61 & 51 \\
\hline alka & $\mathrm{RF}$ & 2.42 & 49.98 & 371 & 15.61 & 15.61 & 48 & 0 & 6 & & 53 & .72 & & 526 & 5 & 52 \\
\hline alka & & 45 & 45.28 & 330 & 15.76 & 14.32 & 299 & & 13 & & 3 & 05 & & 294 & & 31 \\
\hline alkal & & & 495 & 328 & .78 & 4.09 & & .75 & 66 & & & 01 & & 291 & & 33 \\
\hline alka & & & & 02 & 36 & .75 & & & & & 4 & 34 & & 10 & 8 & 34 \\
\hline alkali & & & .85 & 31 & & 14.59 & & 47 & 19 & & 18 & 87 & & 32 & & 8 \\
\hline alka & & & 13 & 2 & & & & & 1 & 26 & 3 & 90 & & 8 & & 8 \\
\hline alk & & & 95 & 971 & & & & & 99 & & 37 & 93 & & & & 7 \\
\hline & B & & 46.74 & 2.611 & & & & & 4.96 & 11 & 97 & 88 & & 60 & & 1 \\
\hline & & & 46.48 & 2.554 & 68 & 6 & & 1 & .77 & & 89 & 95 & .1 & 480 & & 55 \\
\hline all & B & & 48.46 & 2.706 & & & & & 1 & 2 & 66 & 03 & & 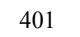 & 0 & 31 \\
\hline alkal & & & 46.77 & 2.989 & & 14.65 & & 9 & 26 & 3 & 52 & 3 & & & & 24 \\
\hline alkal & & & 50.44 & 2.844 & & 14.94 & & 02 & 33 & 6 & 5 & 92 & & & & 25 \\
\hline alkali & & & 46.51 & 3.780 & 15.99 & 16.20 & 15 & 4.02 & 6.17 & 4.40 & 90 & 63 & & 293 & & 18 \\
\hline alkali & & & 45.86 & 3.676 & & 15.5 & & 3.91 & 6 & & 39 & 63 & & 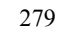 & & 27 \\
\hline alkali & & & 45.92 & 3.573 & 16.56 & 16.63 & 52 & 3. & 0 & 3.66 & 10 & 2 & 99.37 & 292 & 6 & 19 \\
\hline vitric fel & & & 62.78 & 0.253 & 14.96 & 6.01 & 118 & 2.36 & .67 & 0.63 & 5.83 & 0.05 & 101.09 & 3092 & 460 & 160 \\
\hline fine fel & $\mathrm{HRL}$ & & 74.57 & 0.238 & 9.64 & 3.61 & .060 & 1.45 & 0.61 & 0.70 & 3.23 & 0.07 & 99.18 & 1409 & 218 & 112 \\
\hline fine fels & HRFF & 32 & 71.84 & 0.352 & 10.89 & 4.17 & 0.100 & 2.30 & 0.57 & 0.35 & 3.80 & 0.08 & 99.77 & 1923 & 260 & 141 \\
\hline felsi & $H$ & 3.13 & 67.83 & .452 & 13.74 & 3.7 & 054 & 7 & 1.33 & 3.57 & 3.89 & 0.13 & 98.78 & 405 & 18 & 24 \\
\hline & & & 70 & 3 & 13. & & 2 & & 1.42 & 3.81 & 4.13 & 0.15 & 100.7 & 41 & & 28 \\
\hline & & 1.9 & 71.32 & 0.325 & 12 & 3.84 & 0.047 & & 1.36 & 4.05 & 3.34 & 0.10 & 99.79 & 32 & 15 & 32 \\
\hline & & 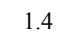 & 72.08 & 0.299 & 13.33 & 2.49 & 0.046 & & 1.18 & & 4.1 & 8 & 99.24 & 299 & 17 & 45 \\
\hline felsic clast & . & 2.09 & 70.01 & 0.441 & 13.36 & 4.13 & 0.055 & 0.44 & 1.51 & 2.95 & 4.76 & 0.13 & 99.88 & 402 & 15 & 32 \\
\hline trachyte & Ave. $(n=7)^{1}$ & 2.68 & 63.01 & 0.509 & 14.13 & 7.01 & 0.191 & 0.22 & 2.41 & 4.30 & 4.93 & 0.15 & 99.53 & 946.57 & 84.61 & 75.5 \\
\hline rhyolite & Ave. $(n=8)^{1}$ & 1.47 & 72.93 & 0.173 & 11.56 & 4.02 & 0.085 & 0.02 & 0.22 & 4.17 & 4.64 & $\operatorname{tr}$ & 99.27 & 2368.8 & 251.4 & 179 \\
\hline MI alkali basalt & Ave. $(n=34)^{2}$ & 6.61 & 44.16 & 2.26 & 16.28 & 11.24 & 0.16 & 8.41 & 3.6 & 0.94 & 5.1 & 0.56 & 99.32 & 230 & 47 & 29 \\
\hline MI tholeiitic basalt & Ave. $(\mathrm{n}=18)^{2}$ & .89 & 44.00 & 510 & 16.80 & 11.37 & 0.170 & 9.64 & 5.71 & 1.10 & 3.33 & 0.23 & 99.74 & 108 & 11 & 24 \\
\hline
\end{tabular}

\section{Table 1.}




\begin{tabular}{cccccccccccccccccc}
\hline Lithology & Sample & Th & Ta & Nb & La & Ce & Nd & Zr & Hf & Sm & Eu & Tb & Y & Ho & Tm & Yb & Lu \\
& detection limit & 0.1 & 0.1 & 1 & 0.1 & 0.1 & 0.1 & 2 & 0.2 & 0.1 & 0.05 & 0.1 & 1 & 0.1 & 0.05 & 0.1 & 0.01 \\
felsic clast & HRFB5 & 18.3 & 1.6 & 18 & 42.1 & 108.0 & 37.7 & 405 & 9.4 & 7.0 & 1.54 & 0.9 & 24 & 1.0 & 0.41 & 3.0 & 0.49 \\
felsic clast & HRFB4 & 18.2 & 1.6 & 19 & 36.0 & 79.8 & 35.0 & 418 & 10.1 & 7.3 & 1.79 & 1.0 & 28 & 1.2 & 0.52 & 3.5 & 0.57 \\
felsic clast & HRFB3 & 21.5 & 1.4 & 15 & 45.0 & 115.0 & 42.3 & 324 & 7.7 & 8.4 & 1.51 & 1.2 & 32 & 1.3 & 0.56 & 3.8 & 0.61 \\
felsic clast & HRFB2 & 25.8 & 1.8 & 17 & 55.1 & 125.0 & 49.7 & 299 & 7.4 & 10.3 & 1.26 & 1.5 & 45 & 1.8 & 0.75 & 5.0 & 0.76 \\
felsic clast & HRFB1 & 16.7 & 1.7 & 15 & 50.0 & 116.0 & 40.4 & 402 & 9.0 & 8.5 & 1.92 & 1.2 & 32 & 1.4 & 0.62 & 3.9 & 0.56 \\
alkali basal1 & RR1 & 3.2 & 3.1 & 39 & 39.7 & 89.5 & 50.1 & 291 & 6.2 & 11.8 & 3.59 & 1.5 & 33 & 1.5 & 0.51 & 2.9 & 0.46 \\
alkali basal1 & Q3 & 4.3 & 3.7 & 50 & 48.2 & 105.0 & 57.0 & 382 & 8.1 & 12.5 & 4.12 & 1.6 & 38 & 1.6 & 0.61 & 3.8 & 0.58 \\
alkali basal1 & HR2 & 2.9 & 2.7 & 53 & 31.6 & 68.3 & 37.4 & 279 & 5.4 & 8.3 & 2.72 & 1.1 & 27 & 1.0 & 0.35 & 2.2 & 0.36 \\
alkali basal1 & B3 & 5.2 & 4.6 & 62 & 72.4 & 156.0 & 86.0 & 480 & 10.3 & 19.0 & 5.54 & 2.4 & 55 & 2.4 & 0.84 & 5.4 & 0.79 \\
MI tholeiitic basal1 & Ave. (n=18) & 1.1 & 0.6 & 11 & 9.5 & 22.3 & 14.0 & 108 & 2.4 & 3.5 & 1.32 & 0.7 & 24 & 0.9 & 0.36 & 2.3 & 0.36 \\
MI alkali basalt & Ave. $(\mathrm{n}=34)^{2}$ & 4.1 & 3.1 & 47 & 33.6 & 70.0 & 32.7 & 230 & 5.0 & 6.9 & 2.27 & 1.0 & 29 & 1.1 & 0.41 & 2.6 & 0.41 \\
\hline
\end{tabular}

Table 2. 


\begin{tabular}{|c|c|c|c|c|c|c|c|c|c|c|c|c|c|c|c|c|c|c|c|c|}
\hline $\begin{array}{l}\text { Sample/ } \\
\text { Analysis No. }\end{array}$ & $\begin{array}{c}\text { Weight } \\
(\mu \mathrm{g})\end{array}$ & $\underset{(\mathrm{ppm})}{U}$ & $\mathrm{Th} / \mathrm{U}$ & $\begin{array}{l}\mathrm{Pb}_{\mathrm{c}} \\
(\mathrm{pg})\end{array}$ & $\begin{array}{l}\mathrm{Pb}_{\mathrm{T}} / \\
\mathrm{Pb}_{\mathrm{C}}\end{array}$ & $\begin{array}{c}{ }_{{ }^{206} \mathrm{~Pb} /} \\
{ }^{204} \mathrm{~Pb} \\
\text { measured }\end{array}$ & ${ }^{207} \mathrm{~Pb} /$ & $2 \sigma$ & $\begin{array}{l}{ }^{206} \mathrm{~Pb} / \\
{ }^{238} \mathrm{U}\end{array}$ & $2 \sigma$ & $\begin{array}{l}\text { Err } \\
\text { Corr }\end{array}$ & $\begin{array}{l}{ }^{207} \mathrm{~Pb} / \\
{ }^{206} \mathrm{~Pb} /\end{array}$ & $2 \sigma$ & $\begin{array}{c}{ }^{206} \mathrm{~Pb} / \\
{ }^{238} \mathrm{U} \\
\text { Age (Ma) }\end{array}$ & $2 \sigma$ & $\begin{array}{c}{ }^{207} \mathrm{~Pb} / \\
{ }^{235} \mathrm{U} \\
\text { Age (Ma) }\end{array}$ & $2 \sigma$ & $\begin{array}{c}{ }^{207} \mathrm{~Pb} / \\
{ }^{206} \mathrm{~Pb} \\
\text { Age (Ma) }\end{array}$ & $2 \sigma$ & $\%$ Disc \\
\hline$H R v T$ & \multicolumn{20}{|c|}{ Felsic tuff; sampled $1 \mathrm{~m}$ above sample HKLT $\left(46^{\circ} 08^{\prime} 30.83^{\prime \prime} \mathrm{N} 66^{\circ} 03^{\prime} 50.70^{\prime \prime} \mathrm{W}\right)$} \\
\hline $\mathrm{Z1}$ & 17.4 & 105 & 0.68 & 0.7 & 281 & 16487.1 & 0.8443 & 0.0015 & 0.10117 & 0.00012 & 0.882 & 0.06052 & 0.00005 & 621.27 & 0.71 & 621.5 & 0.80 & 622.4 & 1.9 & 0.2 \\
\hline Z2 & 14.7 & 170 & 1.35 & 0.4 & 407 & 20536.9 & 0.3914 & 0.0010 & 0.05344 & 0.00007 & 0.673 & 0.05312 & 0.00010 & 335.60 & 0.40 & 335.4 & 0.70 & 333.8 & 4.2 & -0.6 \\
\hline Z3 & 11.3 & 521 & 0.58 & 0.6 & 528 & 31824.9 & 0.3906 & 0.0005 & 0.05327 & 0.00004 & 0.888 & 0.05318 & 0.00005 & 334.56 & 0.21 & 334.8 & 0.39 & 336.4 & 1.9 & 0.6 \\
\hline Z4 & 8.3 & 195 & 1.35 & 0.7 & 161 & 8134.1 & 0.3807 & 0.0012 & 0.05214 & 0.00014 & 0.932 & 0.05296 & 0.00006 & 327.65 & 0.88 & 327.6 & 0.87 & 327.1 & 2.6 & -0.2 \\
\hline$H R L T$ & \multicolumn{20}{|c|}{ Felsic tuff from near the base of the Hardwood Ridge Volcanic Member along Newcastle Creek $\left(46^{\circ} 08^{\prime} 30.83^{\prime \prime} \mathrm{N} 66^{\circ} 03^{\prime} 50.70^{\prime \prime} \mathrm{W}\right.$} \\
\hline Z1 & 20.0 & 50 & 0.50 & 1.2 & 46 & 2856.2 & 0.3935 & 0.0012 & 0.05364 & 0.00008 & 0.661 & 0.05321 & 0.00012 & 336.83 & 0.49 & 336.9 & 0.86 & 337.8 & 5.3 & 0.3 \\
\hline Z2 & 12.8 & 43 & 0.54 & 0.4 & 72 & 4401.0 & 0.3922 & 0.0018 & 0.05350 & 0.00007 & 0.509 & 0.05317 & 0.00022 & 335.96 & 0.42 & 336.0 & 1.34 & 336.2 & 9.5 & 0.1 \\
\hline$Z 3$ & 13.1 & 50 & 0.56 & 1.5 & 25 & 1544.2 & 0.3918 & 0.0028 & 0.05347 & 0.00011 & 0.504 & 0.05314 & 0.00033 & 335.78 & 0.65 & 335.7 & 2.01 & 334.8 & 14.2 & -0.3 \\
\hline Z4 & 9.9 & 64 & 0.50 & 0.5 & 65 & 4037.7 & 0.3911 & 0.0009 & 0.05337 & 0.00004 & 0.645 & 0.05315 & 0.00011 & 335.17 & 0.27 & 335.2 & 0.69 & 335.2 & 4.5 & 0.0 \\
\hline$F B 5$ & \multicolumn{20}{|c|}{ Felsic volcanic boulder from conglomerate of the Shin Member along Newcastle Creek $\left(46^{\circ} 08^{\prime} 21.34^{\prime \prime} \mathrm{N} 66^{\circ} 04^{\prime} 55.28^{\prime \prime} \mathrm{W}\right.$} \\
\hline $\mathrm{Z1}$ & 23.4 & 42 & 0.71 & 1.8 & 36 & 2121.2 & 0.4406 & 0.0028 & 0.05928 & 0.00008 & 0.539 & 0.05391 & 0.00031 & 371.25 & 0.48 & 370.7 & 1.97 & 367.3 & 12.9 & -1.1 \\
\hline Z2 & 15.0 & 173 & 0.60 & 0.6 & 276 & 16554.7 & 0.4390 & 0.0012 & 0.05894 & 0.00010 & 0.741 & 0.05402 & 0.00010 & 369.17 & 0.60 & 369.6 & 0.87 & 371.9 & 4.3 & 0.8 \\
\hline$Z 3$ & 10.0 & 74 & 0.78 & 0.6 & 84 & 4864.4 & 0.4383 & 0.0015 & 0.05894 & 0.00008 & 0.607 & 0.05393 & 0.00016 & 369.20 & 0.47 & 369.0 & 1.09 & 368.0 & 6.6 & -0.3 \\
\hline$Z 4$ & 22.5 & 74 & 0.68 & 1.0 & 102 & 6021.2 & 0.4377 & 0.0008 & 0.05880 & 0.00006 & 0.771 & 0.05398 & 0.00007 & 368.35 & 0.34 & 368.6 & 0.58 & 370.2 & 2.9 & 0.5 \\
\hline
\end{tabular}




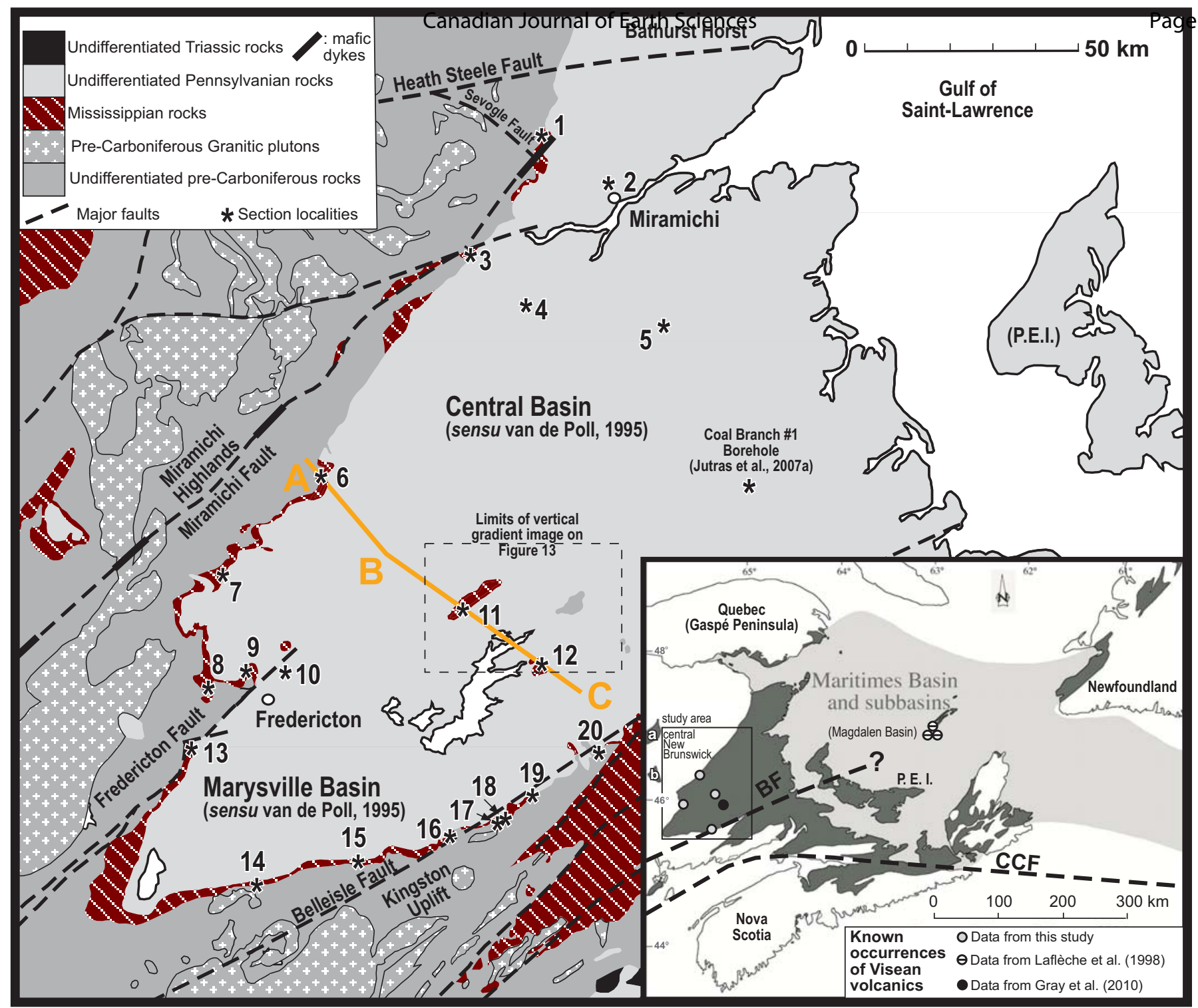

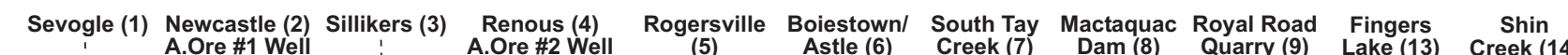

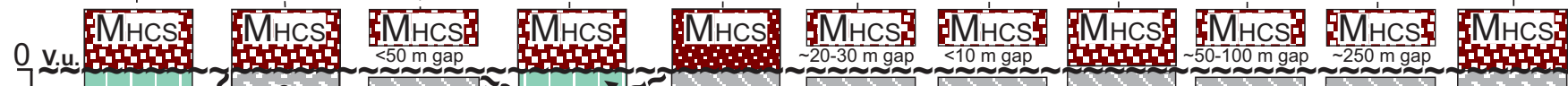
D.u. $\begin{gathered}\text { MLC } \\ \text { D.u }\end{gathered}$ $\mathrm{m}$ OT

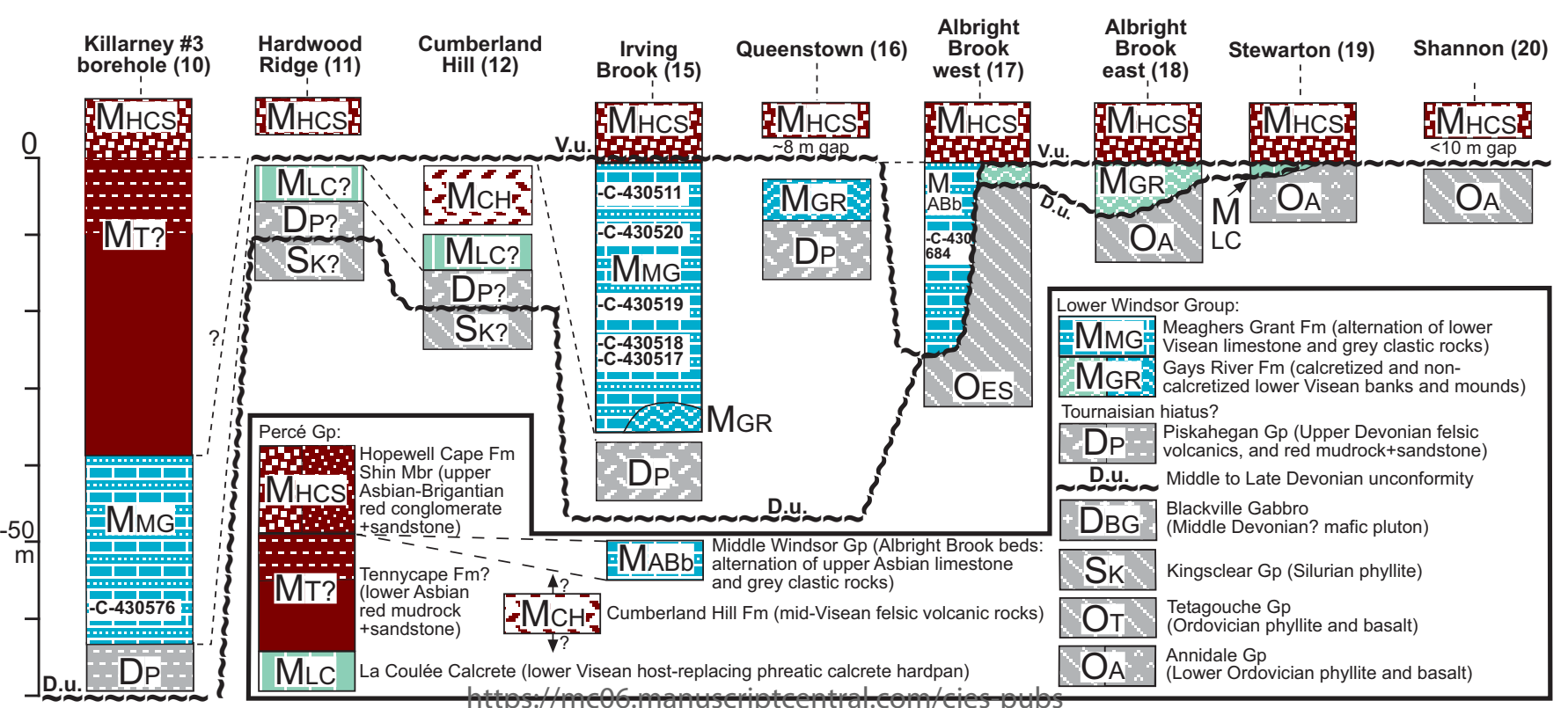

Fig. 1 


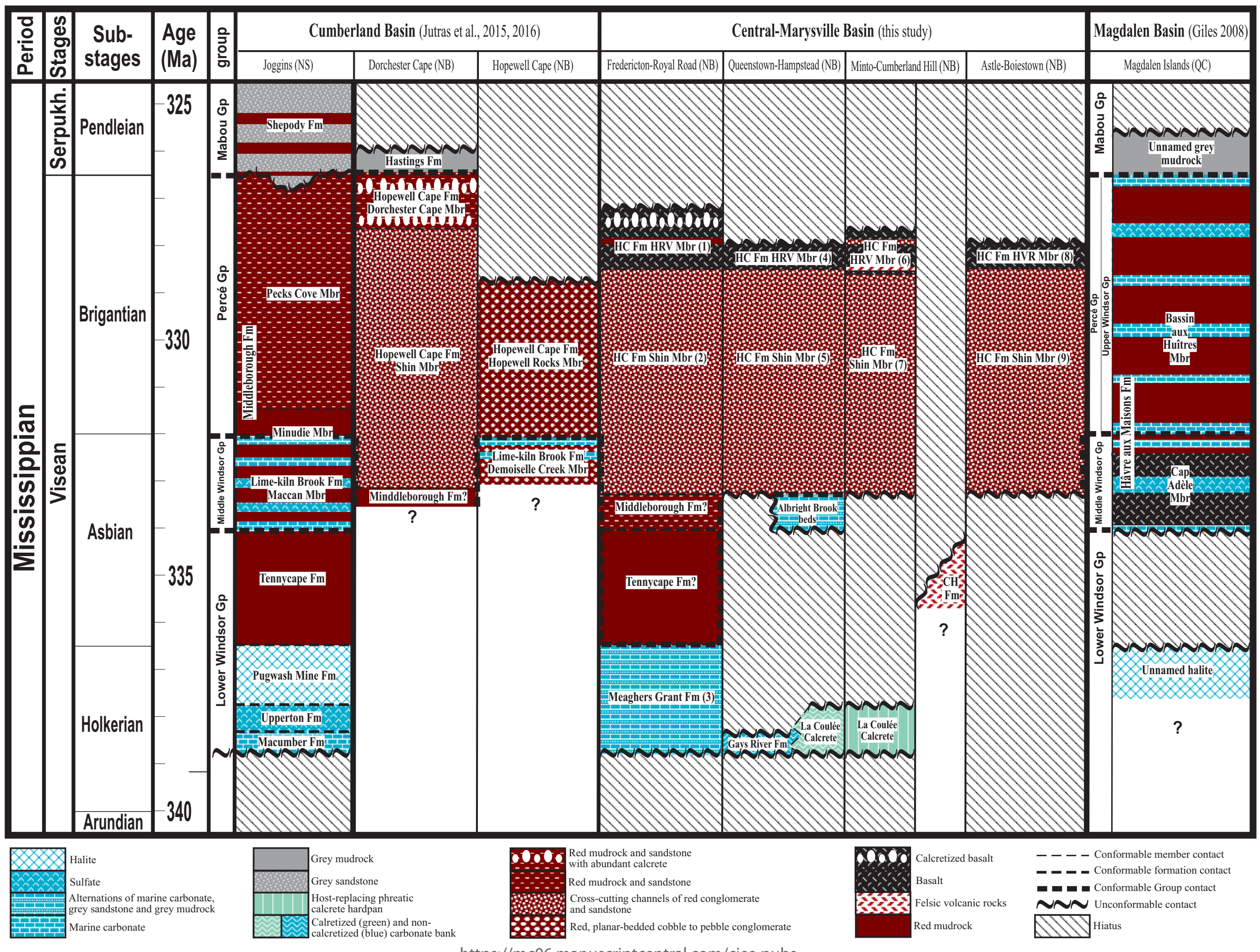

Fig. 2 


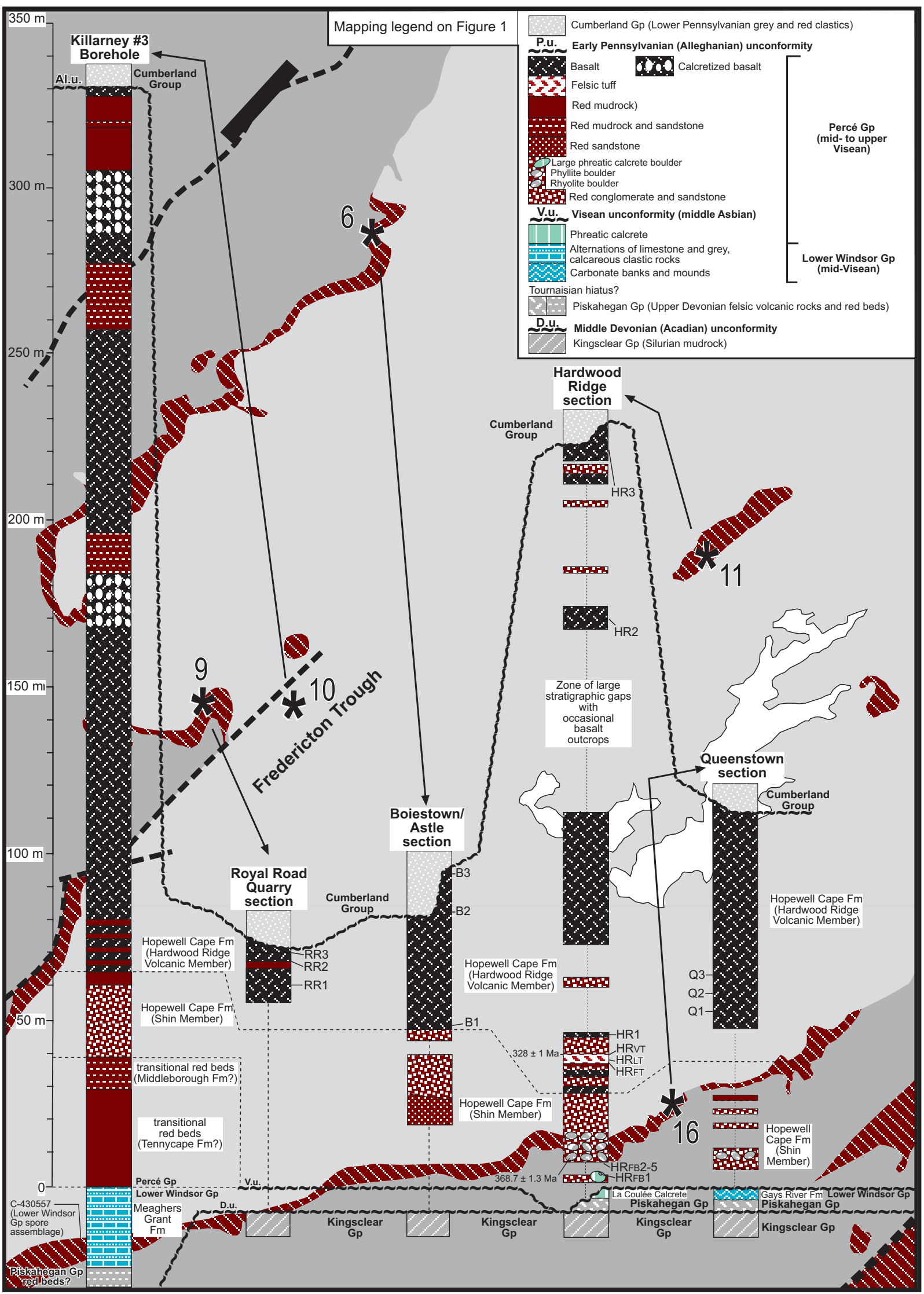

Fig. 3 


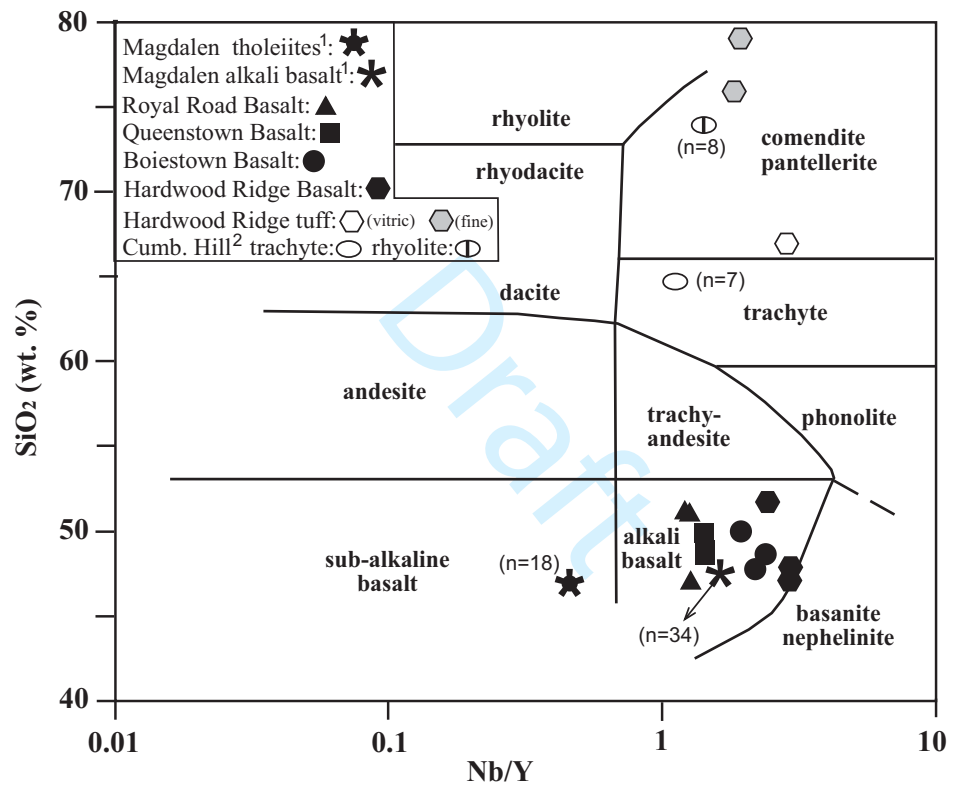

Fig. 4 


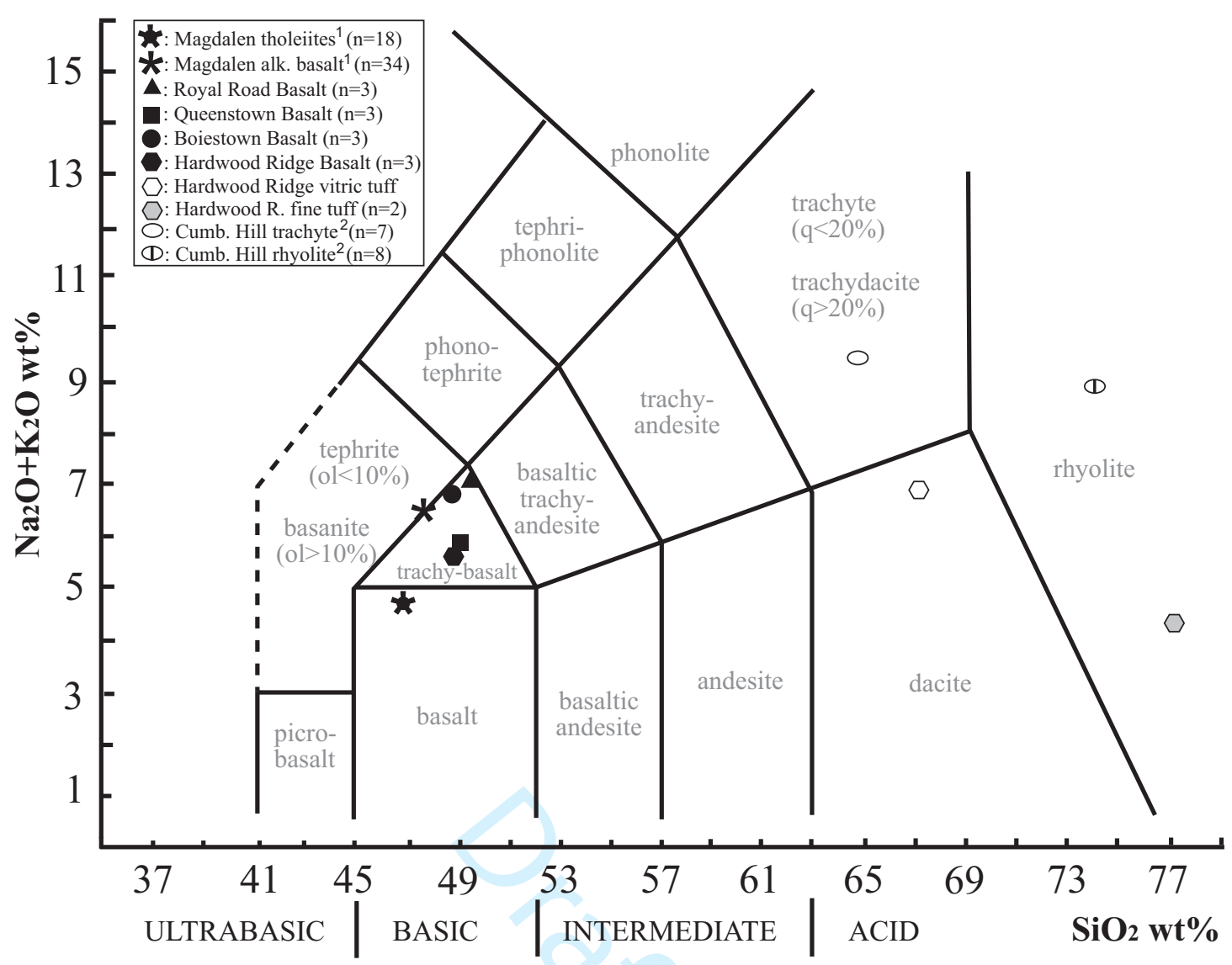

Fig. 5 


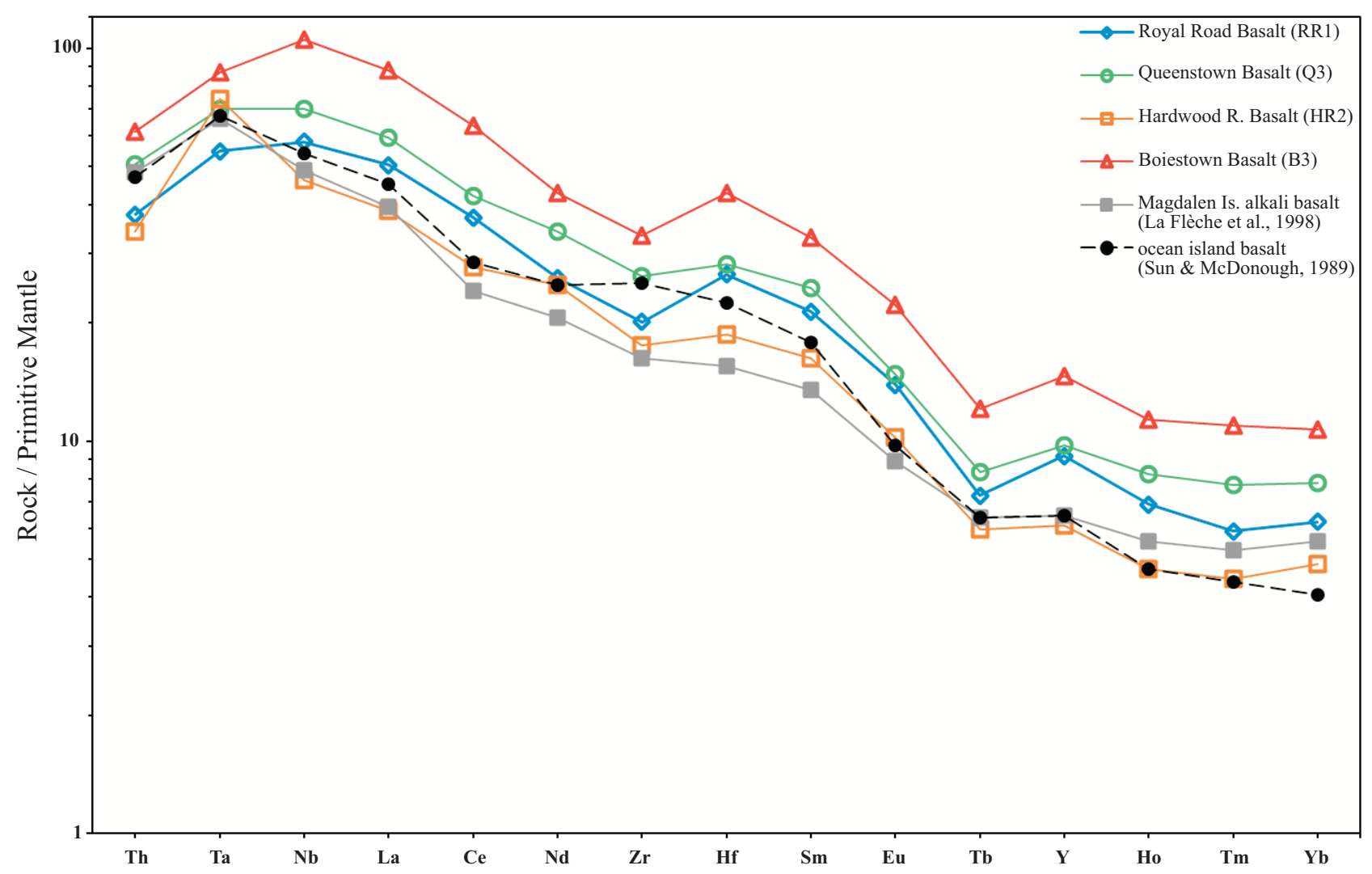

Fig. 6 


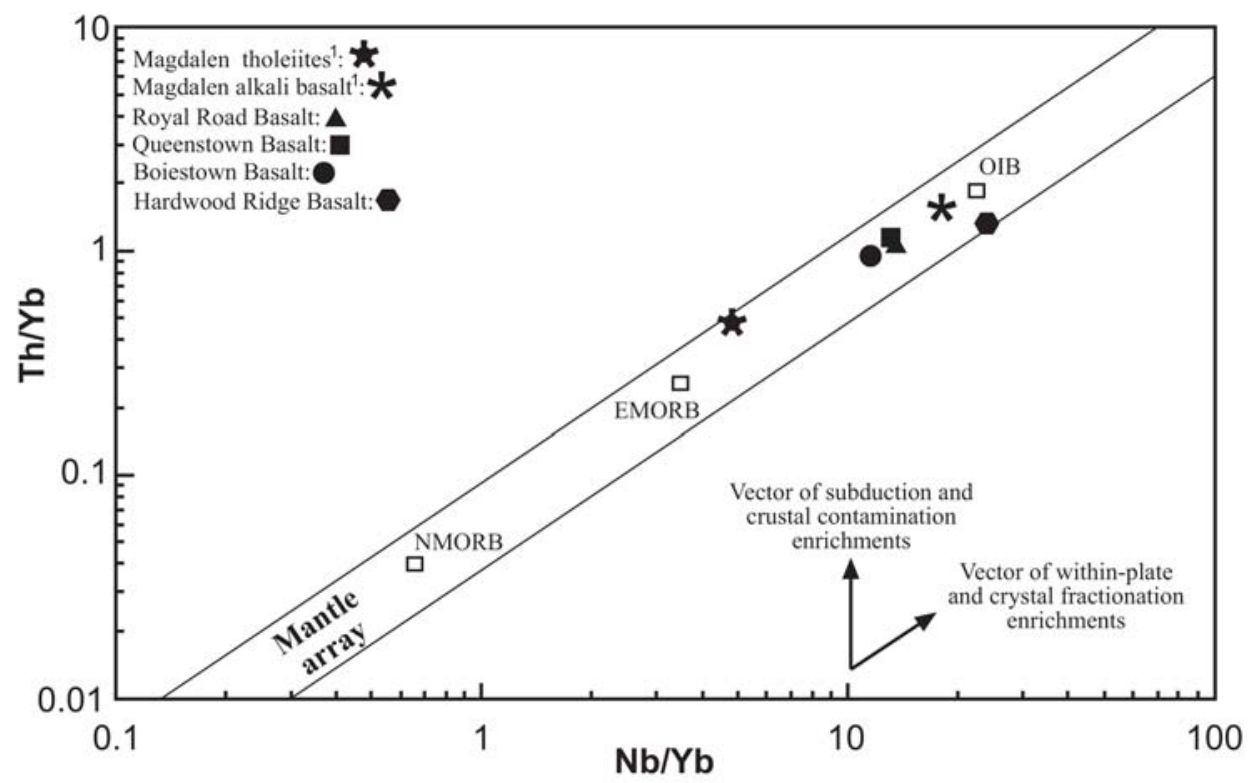

Fig. 7 


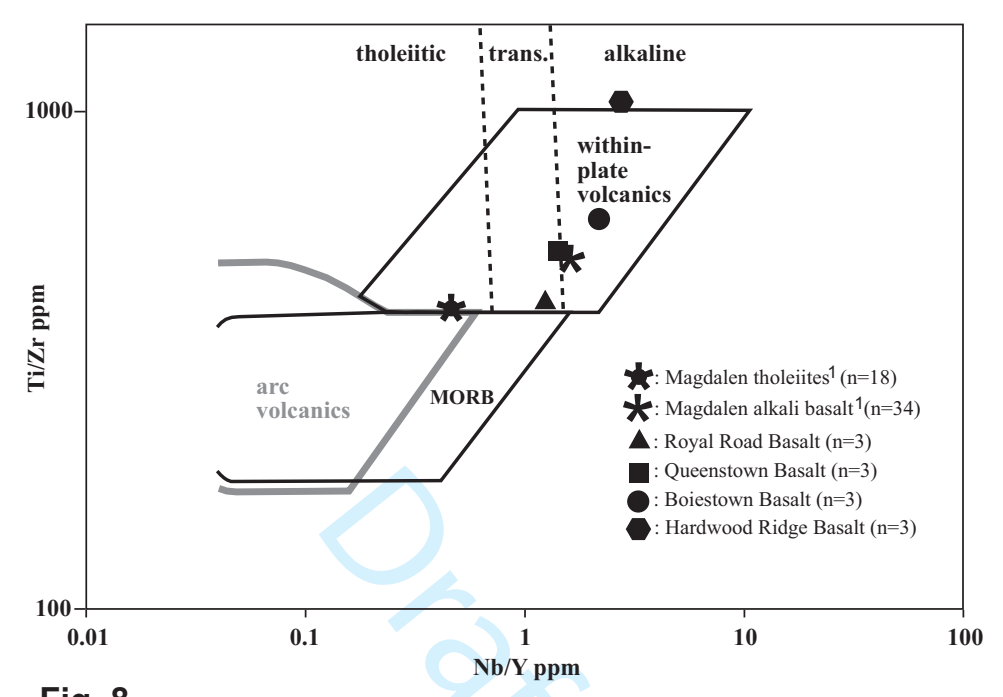

Fig. 8 

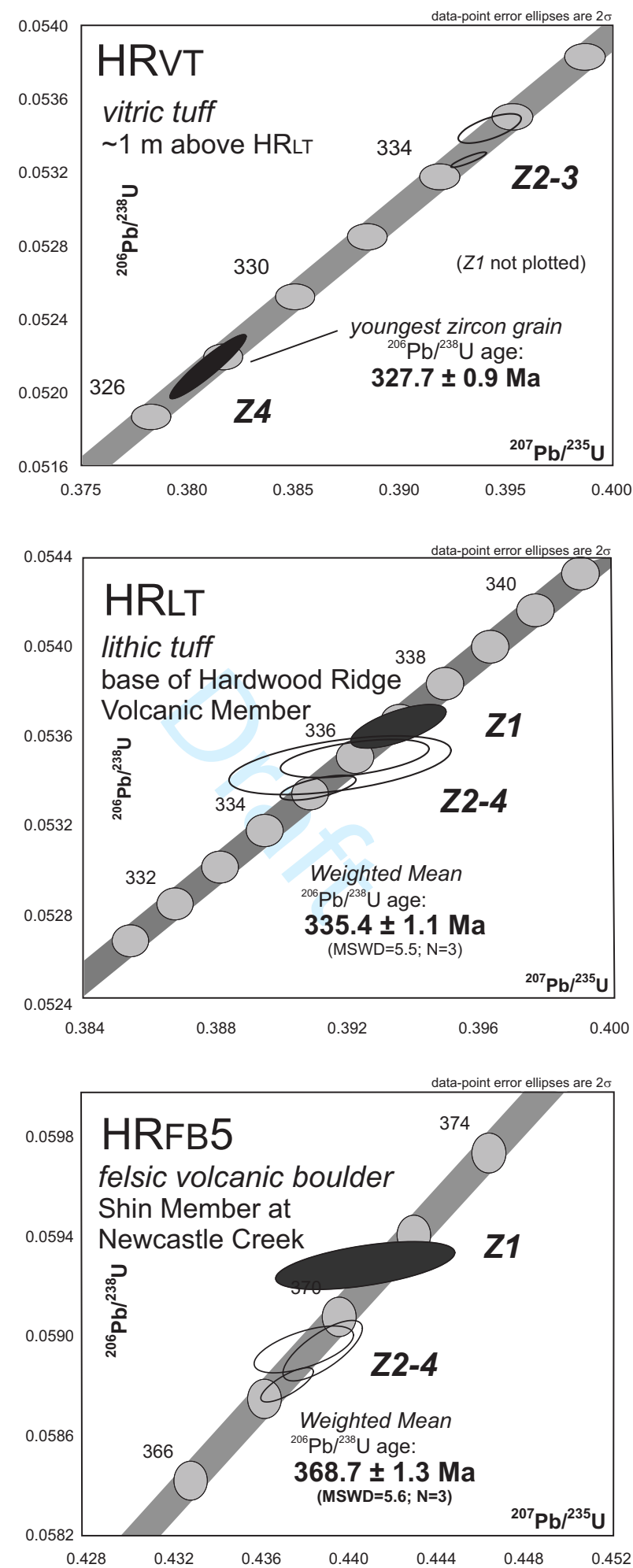

Fig. 9 


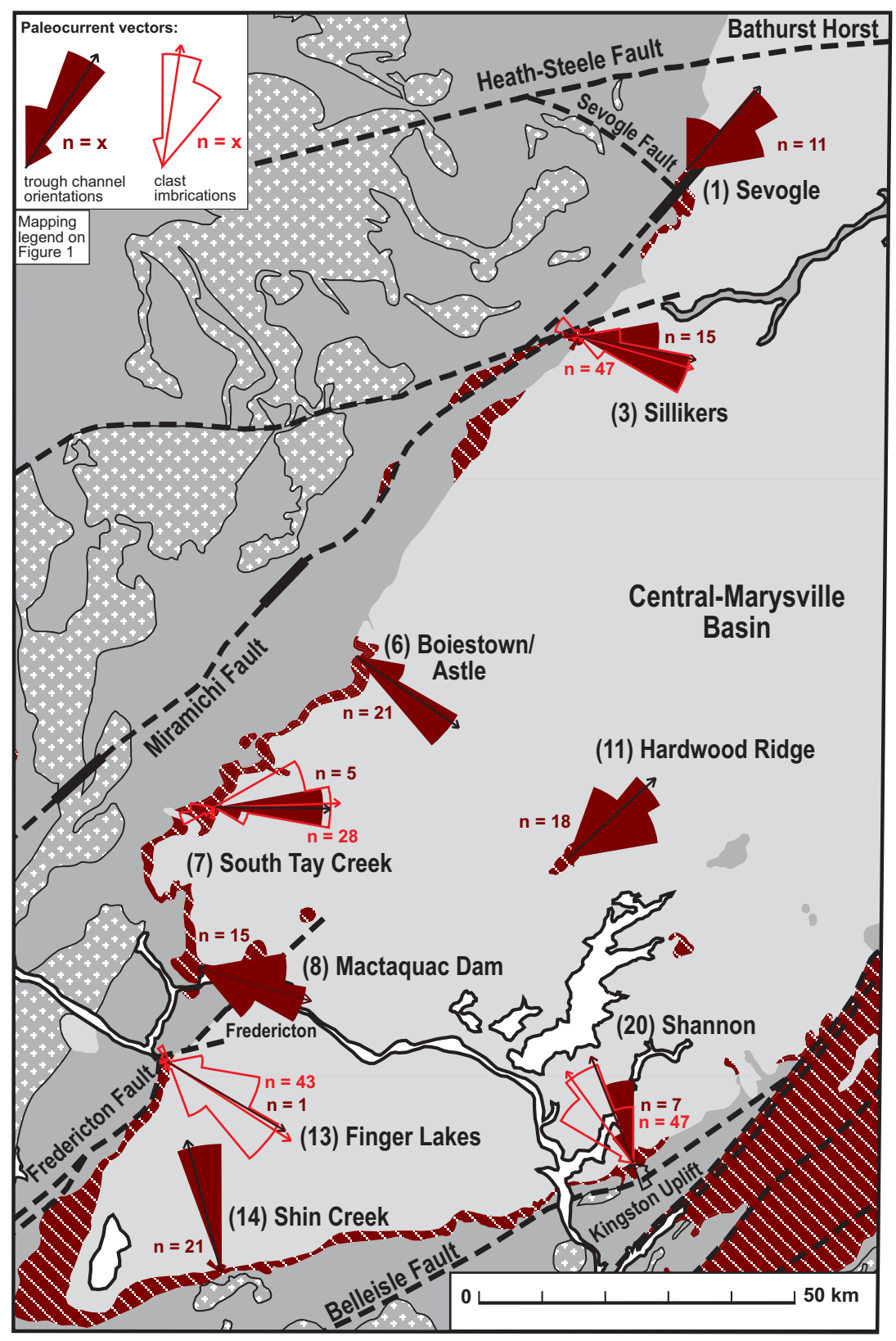

Fig. 10 


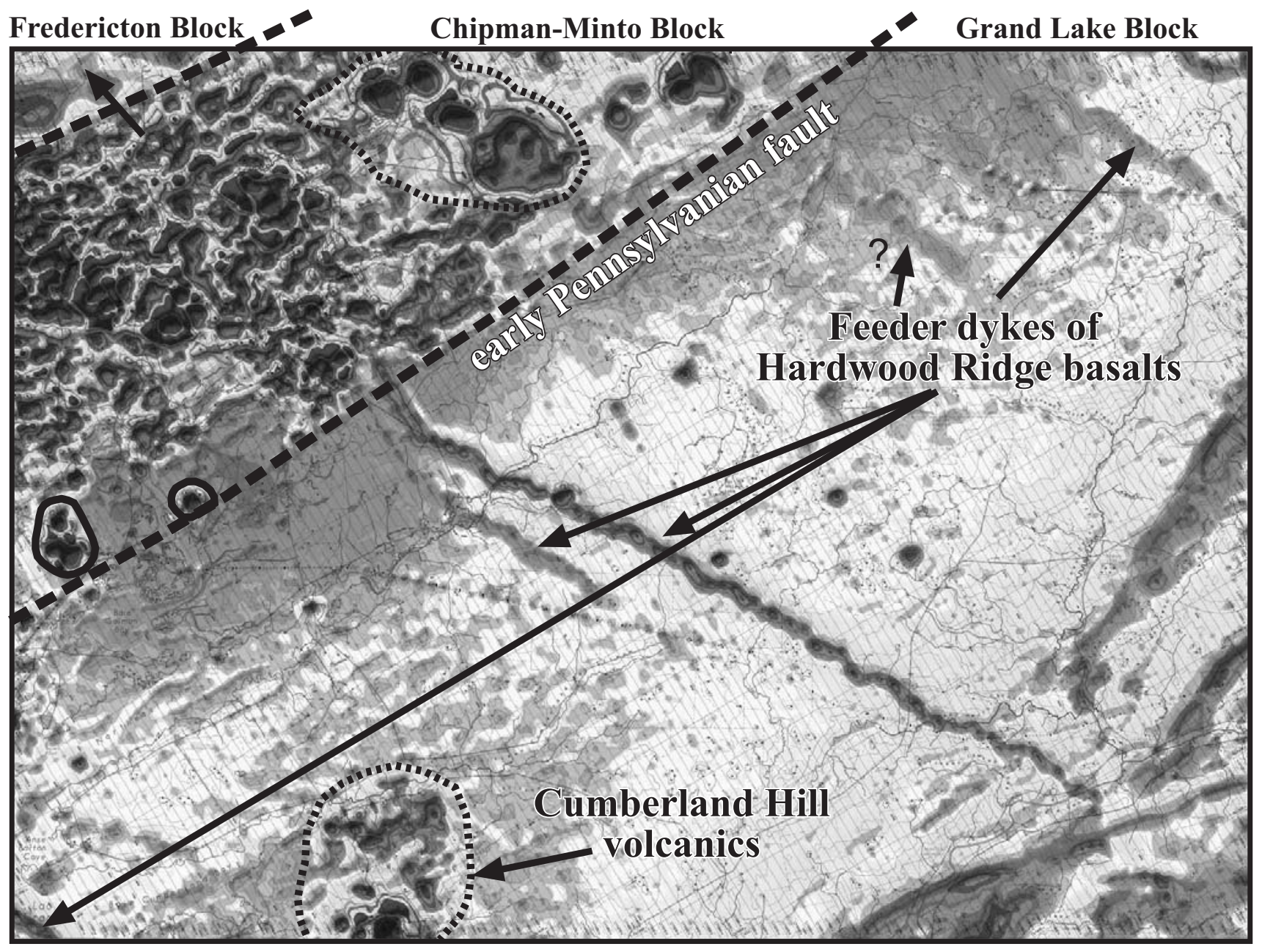

Fig. 11 


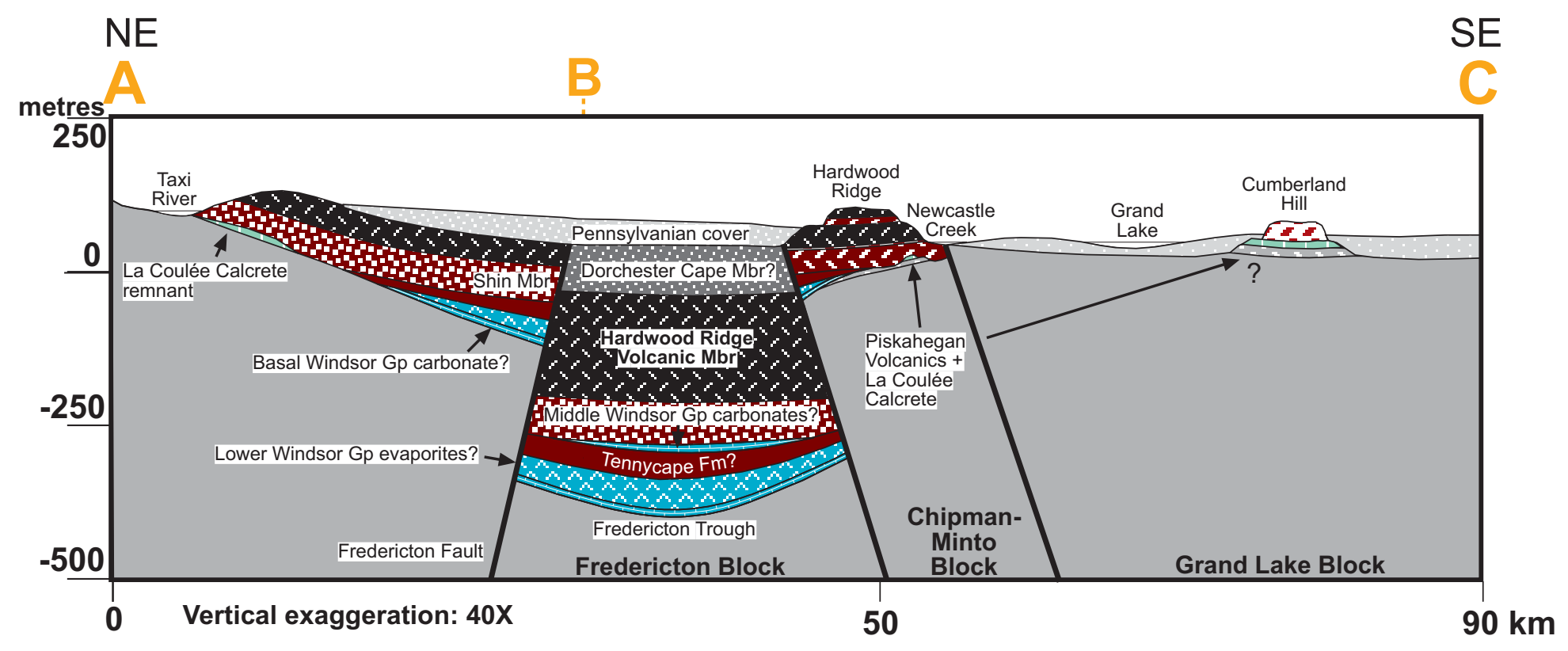

Fig. 12 


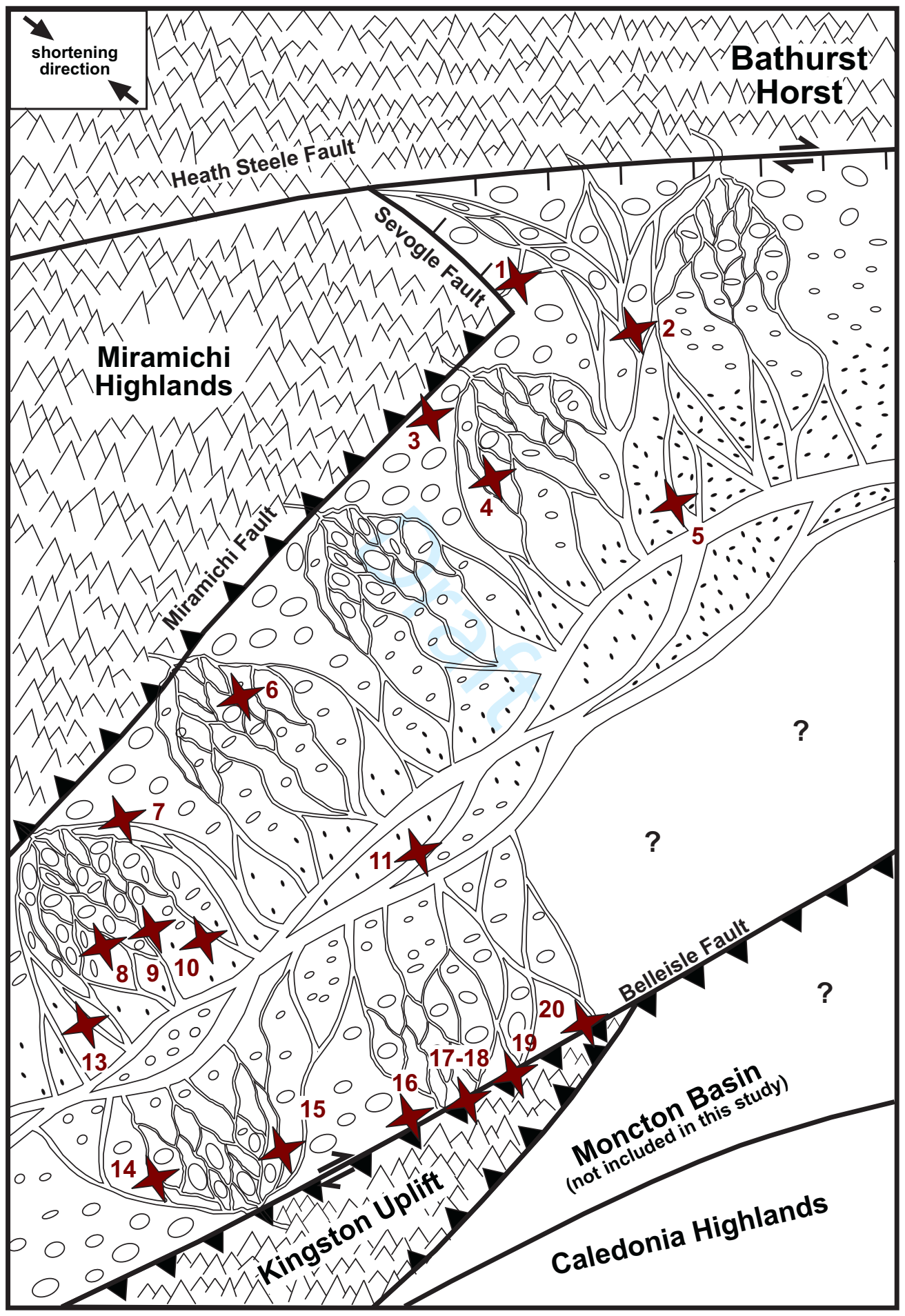

Fig. 18 


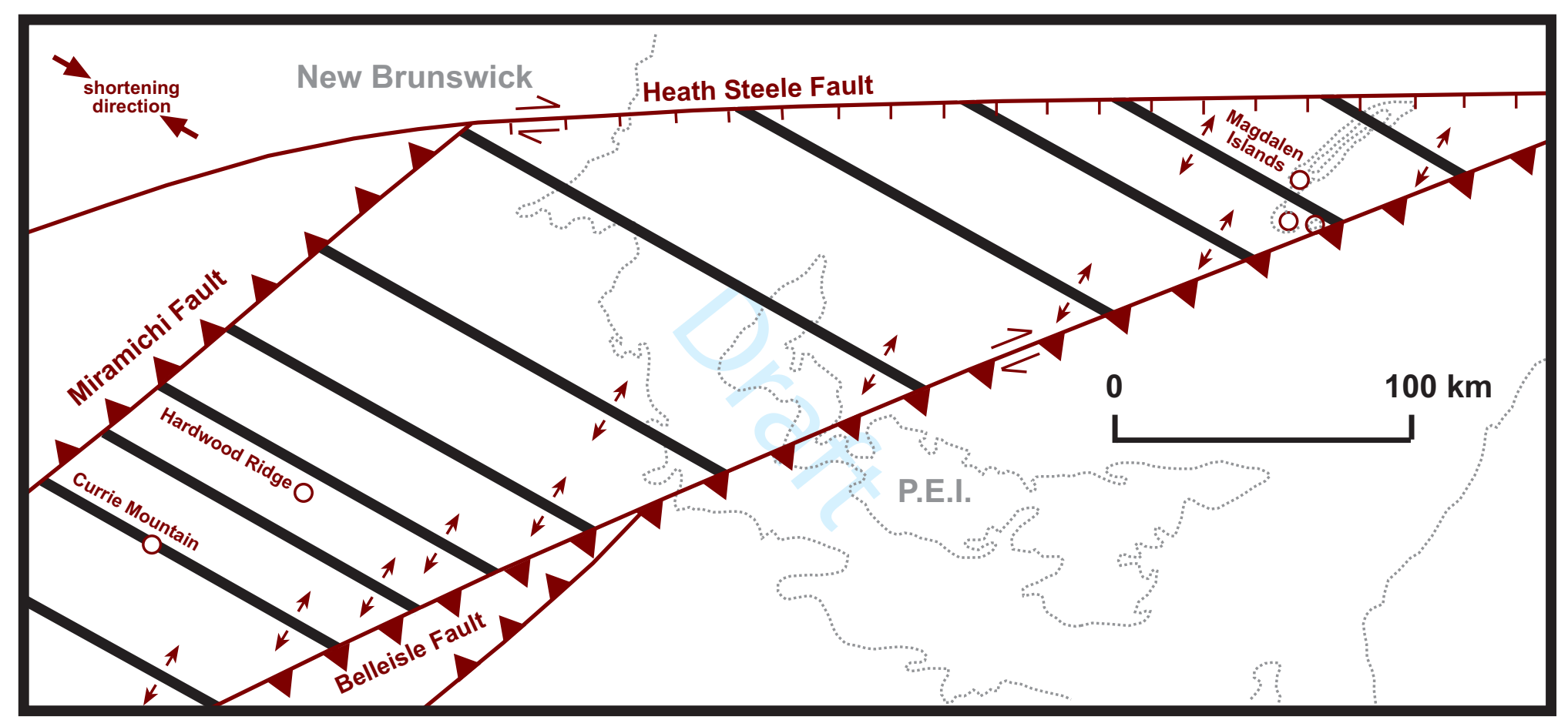

Fig. 14 